\title{
OS CRITÉRIOS PARA IDENTIFICAÇÃO DAS CAUSAS SUPRALEGAIS DE INEXIGIBILIDADE DE CONDUTA DIVERSA JÁ RECONHECIDAS NO DIREITO BRASILEIRO E ESTRANGEIRO
}

THE CRITERIA FOR IDENTIFYING THE SUPRALEGAUS CAUSES OF NO EXIGIBILITY OF CONDUCT ALREADY RECOGNIZED IN BRAZILIAN AND FOREIGN LAW

Maria Carolina de Melo Amorim ${ }^{1}$ PUC/SP

\section{Resumo}

A partir do estudo de casos concretos e exposição doutrinária, tenta-se identificar os tipos de causas supralegais de inexigibilidade de conduta diversa, como elemento da culpabilidade, já conhecidos e admitidos na jurisprudência, assim como os requisitos para sua constatação. Identifica-se, também, novas causas supralegais que não se enquadram nos modelos doutrinariamente estabelecidos, chegando-se a uma nova classificação, intitulada de inexigibilidade de conduta diversa por reação à violação de direito fundamental.

\section{Palavras chave}

Culpabilidade. Inexigibilidade de conduta diversa. Causa supralegal

\section{Abstract}

From the study of concrete cases and doctrinal exposition, an attempt is made to identify the types of supra-legal causes of no exigibility of conduct, as an element of guilt, already known and admitted in the jurisprudence, as well as the requirements for its finding. It also

\footnotetext{
${ }^{1}$ Doutoranda em Direito pela PUC/SP
} 
identifies new supra-legal causes that do not fit in the doctrinally established models, arriving at a new classification, titled of no exigibility of conduct diverse by reaction to the violation of fundamental right.

\section{Keywords}

Guilt. No exigibility of conduct. Supralegal cause

\section{INTRODUÇÃO}

Considerando o conceito tripartido de delito, o crime é fato típico, antijurídico e culpável. A culpabilidade, terceiro elemento dessa concepção, é verificada, por sua vez, quando presentes seus três requisitos, quais sejam, a imputabilidade, a consciência da antijuridicidade e a exigibilidade de comportamento diverso, essa última traduzida na possibilidade de exigir-se do autor de uma conduta típica e antijurídica que se portasse de acordo com a lei.

Partindo-se do conceito normativo de culpabilidade, a exigibilidade de comportamento conforme o direito é o terceiro estágio do juízo de reprovação da culpabilidade (junto à imputabilidade e consciência da antijuridicidade), e tem como fundamento concreto a normalidade das circunstâncias do fato ${ }^{2}$.

Assim, para que uma ação possa se dizer culpável, não basta que o sujeito seja tido como capaz, imputável, e tenha consciência do injusto que representa seu ato, fazendo-se necessário, ainda, que tenha podido determinar-se normalmente rumo à prática do ato. Tal "determinação normal" não é verificada quando as circunstâncias reais

${ }^{2}$ CIRINO DOS SANTOS, Juarez. Direito Penal: Parte Geral. 2a ed. Curitiba: ICPC Editora Lúmen Iuris, 2007, p. 324. 
que compõem o atuar do indivíduo forem de tal ordem que tornem impossível ou muito difícil a formação de um querer imune de defeitos ${ }^{3}$.

Na sua concepção normativa, a culpabilidade desapareceria quando - dadas as condições e circunstâncias que permeiam a conduta - não se puder exigir do sujeito ativo um comportamento diferente daquele por ele efetivamente adotado.

A causas legais de inexigibilidade de conduta diversa no Brasil são, unicamente ${ }^{4}$, (I) a coação moral irresistível e (II) a

${ }^{3}$ BETTIOL, Giuseppe. Direito Penal: Parte Geral. Vol. II. Tradução brasileira e anotações dos professores Paulo José da Costa Jr. e Alberto Silva Franco. São Paulo: RT, 1971, p. 139.

${ }^{4}$ Como já abordado em obra específica da autora, a pontual situação do crime de favorecimento pessoal, na qual o indivíduo auxilia outrem para que esse fuja ou se subtraia das forças policiais (art. 348, parágrafo 2 o do CP), não foi considerada pelo código brasileiro como excludente de culpabilidade, mas escusa absolutória. Além disso, discordamos da doutrina de CIRINO DOS SANTOS (Op. Cit, p. 335), o qual coloca, dentre as causas legais de exculpação no direito brasileiro, o excesso de legítima defesa real e o excesso de legítima defesa putativa. Ora, o primeiro excesso é considerado causa legal de exculpação no direito alemão (§33), que dispõe que "ultrapassando o agente os limites da legítima defesa por perturbação (verwirrung), medo ou susto, não será ele punido", mas o é não no direito brasileiro. E mais: além de não se localizar, no Código Penal brasileiro, a exclusão da culpabilidade para o excesso de legítima defesa (muito pelo contrário, a previsão é de punição pelo excesso doloso ou culposo, pelo art. 23, parágrafo único), deve-se atentar para o fato de que o legislador não faz diferença entre os excessos, deixando de reputá-los "crassos" ou "leves", "imoderados" ou "posteriores", e a exculpante putativa do art. 20, §1ํ do CP relaciona-se ao erro, não a uma situação de inexigibilidade de outra conduta. Nesse sentido, vide AMORIM, Maria Carolina. A Inexigibilidade de Conduta Diversa: os fundamentos para a aplicação das causas supralegais no Direito Penal Brasileiro. Belo Horizonte: Del Rey, 2014. 
obediência hierárquica, ambas elencadas no artigo 22 do Código Penal brasileiro ${ }^{5}$.

No entanto, como o elemento em discussão decorre do próprio conceito de culpabilidade, a exculpação é verificada sempre que não houver liberdade de opção no caso concreto entre se comportar conforme ou contrário ao direito, independentemente de previsão legal ${ }^{6}$. Assim, das causas de exclusão da culpabilidade, a inexigibilidade de conduta diversa é a única que, dada a sua importância e características, pode ser aplicada em situações não abraçadas pelo legislador (supraleais), nas quais, em subordinação às peculiaridades do caso concreto, não se faz possível elaborar juízo de censura ao indivíduo.

Dessa forma, com respaldo na construção doutrinária acerca do tema, algumas condutas não podem ser censuradas, dado o contexto fático na qual se encontram, embora não haja previsão dessa exculpação nos preceitos legislados. Em consequência, difundiu-se a ideia da inexigibilidade de conduta diversa como um fundamento geral de exculpação, insubordinado à lei, por se tratar de dirimente de ampla atuação, relacionada aos próprios princípios do direito penal, legitimando sua aplicação extra legem.

Com base nesse entendimento, a doutrina de ASSIS TOLEDO tem a inexigibilidade de outra conduta como um verdadeiro princípio do direito penal, esclarecendo que, quando inexistente a sua previsão na legislação, "deve ser reputada causa supralegal, erigindo-

\footnotetext{
${ }^{5}$ Código Penal brasileiro: Art. 22 - Se o fato é cometido sob coação irresistível ou em estrita obediência a ordem, não manifestamente ilegal, de superior hierárquico, só é punível o autor da coação ou da ordem.

${ }^{6}$ BRANDÃO, Cláudio. Culpabilidade: sua análise na dogmática e no direito penal brasileiro. In: Revista Portuguesa de Ciência Criminal, Coimbra, noo. 02, p. 209-227, abril-junho 2005, Ano 15.
} 
se em princípio fundamental que está intimamente ligado com o problema da responsabilidade pessoal", o que justificaria a não exigência de normas expressas a respeito ${ }^{7}$.

Um dos obstáculos ao reconhecimento das exculpantes supralegais de culpabilidade é o grande poder conferido aos Juízes de, à revelia da legislação vigente, verificar ou não a reprovabilidade da ação e seu autor. Teme-se, com esse argumento, que o uso dessa tese pela defesa possa conduzir a uma excessiva impunidade dos crimes.

Ora, a partir da compreensão, iniciada por FREUDENTHAL, da inexigibilidade de outra conduta como um conceito geral de exculpação, de inquestionável importância na aplicação do direito mesmo fora dos limites legais, e das inúmeras discussões doutrinárias acerca dos arquétipos de sua utilização, WELZEL $^{8}$ desenvolveu um modelo para o reconhecimento das aludidas causas pelos operadores do direito.

A única dirimente supralegal de exigibilidade de conduta diversa discutida por esse autor é o estado de necessidade exculpante, verificado quando o bem sacrificado na situação de risco é de maior valor do que o salvaguardado (fato que afastaria a aplicação do estado de necessidade como excludente da antijuridicidade). $O$ clássico exemplo welzeliano de inexigibilidade de conduta diversa, baseado na jurisprudência alemã, é o reconhecimento da incensurabilidade da conduta dos médicos que praticaram a eutanásia determinada por Hitler9.

7 TOLEDO, Francisco de Assis. Princípios Básicos do Direito Penal. São Paulo: Saraiva, 2008, p. 328.

${ }^{8}$ WELZEL, Derecho Penal Aleman. Tradução de Juan Bustos Ramírez y Sergio Yáñez Perez. 11a edição. Santiago de Chile: Editorial Jurídica de Chile, 1997, p. 217. 9 O chamado "decreto de eutanásia" de Hitler determinou aos agentes de saúde o envio dos doentes mentais aos campos de concentração. Sabedores de que, se não o 
Dada tal aplicação fora dos limites da lei e a tentativa de WELZEL de identificar pressupostos para o reconhecimento dessas causas, percebe-se a tentativa da doutrina em identificar e delimitar, através de regras abrangentes ${ }^{10}$, as hipóteses nas quais se enquadram as causas supralegais de inexigibilidade de conduta diversa. Tais modelos (de conduta e de circunstâncias) teriam grande valia para guiar os operadores do direito na identificação dessas causas para os casos concretamente analisados.

Com base em conceitos já trabalhados na doutrina alemã e espanhola, a doutrina brasileira reduziu as hipóteses supralegais em quatro fórmulas específicas, quais sejam, (a) o fato de consciência, (b) a provocação da situação de legítima defesa, (c) a desobediência civil e (d) o conflito de deveres ${ }^{11}$.

No entanto, ao contrastar os exemplos welzelianos - que, tendo por pano de fundo as decisões do Tribunal alemão no período pós Segunda Guerra, voltam-se apenas às hipóteses de conflitos de deveres $^{12}$ - com as publicações mais recentes sobre o tema, vê-se que

obedecessem, seriam denunciados por outros médicos complacentes com o regime (o que não evitaria a morte dos mesmos pacientes), alguns médicos optaram por eleger determinados pacientes, atestando-os como aptos ao trabalho ou curáveis, e sacrificar outros, não deixando, assim, de cumprir a ordem ilegal.

10 A ressalva a uma regra abrangente se dá em razão da necessidade de que tal delimitação não crie uma específica situação de exculpação (como a inexigibilidade de recolhimento de contribuições previdenciárias em caso de dificuldades financeiras da empresa), mas apenas pontue regras gerais que auxiliem (e vinculem) o julgador na identificação das causas alegadas nos casos concretos.

${ }^{11}$ Cf. CIRINO DOS SANTOS, Juarez. Op. Cit., p. 322-342.

12 Tendo por base as decisões do Tribunal alemão, WELZEL definiu, como pressupostos da exculpação supralegal, “(I) Que la acción del autor era el único medio para proteger de una desgracia mayor; (II) Que el autor ha elegido realmente el mal menor e (III) Que ha perseguido subjetivamente el fin de salvación.” WELZEL, 
os requisitos cunhados por cada autor detêm estrita relação com o direito aplicado à época de sua publicação. Em outras palavras, as incipientes fórmulas para identificar e agrupar as causas supralegais de inexigibilidade de conduta diversa têm unicamente por base as decisões já postas pelos Tribunais, cada uma à sua época e contexto histórico. A situação de inexigibilidade nasce no plano real, concreto, e, somente depois de acatada pelo direito, passa a ser discutida pela doutrina e colocada dentre os modelos desenvolvidos.

A verificação da jurisprudência brasileira sobre o tema demonstra, também, a fragilidade dessa classificação, refutada por diversos julgados que não se enquadraram a nenhum dos 04 (quatro) modelos doutrinários. Na realidade, a jurisprudência brasileira não se atém a esses modelos, fazendo com que o tema transcenda as hipóteses já delimitadas para se aplicar ou não a inexigibilidade supralegal caso a caso.

Não há como negar o caráter dinâmico do direito, cuja velocidade a lei não consegue acompanhar. Assim, as discussões do processo penal não estão isentas do aparecimento, a cada vez, de novas ocorrências, as quais podem não se enquadrar nos modelos já conhecidos, apresentados pela legislação, ou, ainda, apresentados pela doutrina como causas supralegais de não exigibilidade.

Ao trabalhar a catalogação dos modelos supralegais doutrinariamente estabelecidos, esse estudo se refere às colocações de ROXIN, na Alemanha e, na Espanha, de MUÑOZ CONDE e DE LA CUESTA AGUADO, tendo essa última, inclusive, desenvolvido uma classificação própria para essas causas supralegais. No Brasil, a classificação desses modelos foi delineada por CIRINO DOS SANTOS,

Derecho Penal Aleman. Tradução de Juan Bustos Ramírez y Sergio Yáñez Perez. 11a edição. Santiago de Chile: Editorial Jurídica de Chile, 1997, p. 217. 
que toma por base a doutrina estrangeira de ROXIN, e é também encontrada na obra de ARIEL DOTTI. Procura-se, nesse ponto, explicar e delimitar cada hipótese de inexigibilidade supralegal, apontando seus fundamentos e requisitos.

Cada modelo de conduta responsável pelo reconhecimento judicial da inexigibilidade supralegal é separado e aqui analisado individualmente, com suas características, exemplos e requisitos para configurar na futura decisão judicial. Deixando claro que o rol aqui desenvolvido nunca poderá ser taxativo (já que a aplicação do direito tem caráter dinâmico e as situações fáticas surgem primeiro na aplicação jurisprudencial para depois serem catalogadas dentre os modelos doutrinariamente estabelecidos), esse estudo ousou criar de um novo modelo de conduta, aqui denominado de "A inexigibilidade supralegal como reação à violação de direito fundamental".

\section{DA CATALOGAÇÃO DAS CAUSAS SUPRALEGAIS DE INEXIGIBILIDADE DE CONDUTA DIVERSA.}

Não são de hoje as tentativas da doutrina de catalogar as hipóteses de não exigibilidade de conduta diversa que não encontram amparo na lei.

Na crítica empreendida pela doutrina de ANTOLISEI à admissão das exculpantes supralegais, já se mencionava a ausência de um critério unitário que se pudesse recorrer para delimitar todo tipo de causa de não exigibilidade: explicava o professor da Universidade de Torino que qualquer fórmula que tentasse abraçar os casos possíveis para aplicação da inexigibilidade de conduta diversa supralegal seria 
tão ampla e vaga que poderia dar margem a interpretações diversas e "soluções escandalosas"13.

Nesse artigo, tenta-se provar o contrário: é possível, sim, estabelecer modelos genéricos de conduta para auxiliar o magistrado na identificação de uma causa supralegal de inexigibilidade de conduta diversa, e aqui identifica-se cinco fórmulas nas quais se inserem todas as causas supralegais já reconhecidas pelo direito brasileiro e estrangeiro.

Ora, em se admitindo a possibilidade de exculpar fora dos casos legais e inexistindo uma fórmula na qual se elencassem circunstâncias comuns a todas essas causas de exculpação, natural que fossem firmados modelos de conduta para o reconhecimento daquelas hipóteses, a partir da catalogação das situações já reconhecidas pela jurisprudência. A tentativa teria por escopo a orientação dos Magistrados na solução dos conflitos, o que, também, refutaria as críticas à incerteza jurídica trazida pela admissão das exculpantes supralegais.

Como brevemente exposto na introdução, a tentativa de criação de requisitos para o reconhecimento de hipóteses de inexigibilidade de conduta diversa já fora promovida por WELZEL, quando se tinha à análise, apenas, poucos casos de inexigibilidade reconhecidos pelo Tribunal Alemão.

Afirmou WELZEL, nesse sentido, que o caso mais importante de inexigibilidade de conduta jurídica, no direito penal alemão, seria o estado de necessidade penal dos artigos §54 e §52 (hoje já revogados) do Código Penal alemão.

${ }^{13}$ ANTOLISEI, Francesco. Manuale di Diritto Penale: Parte generale. Milano: Dott A. Giuffre Editore, 1957, p. 304-305. 
É que o direito, segundo WELZEL, não poderia justificar os atentados à integridade corporal ou à vida de terceiros como meio para salvação da vida, mas poderia escusá-lo, porque não se poderia exigir ao autor uma conduta que importasse na debilidade humana: o estado de necessidade dos antigos $\$ 54$ (exculpante) e 52 (justificante) do Código Penal alemão ${ }^{14}$, como causa de exclusão da culpabilidade, baseava-se na ideia de debilidade humana ${ }^{15}$.

Esclarece ASSIS TOLEDO que tais hipóteses de estado de necessidade, por referirem-se apenas à salvaguarda de direitos próprios ou de parentes, foram consideradas muito restritas, levando a doutrina e jurisprudência da Alemanha a construir, diante de casos concretos insolúveis perante o dispositivo mencionado, o estado de necessidade supralegal, apoiado no princípio da ponderação de bens e deveres ${ }^{16}$. Assim teria surgido, para ASSIS TOLEDO, as discussões que precederam a Teoria Diferenciadora (estado de necessidade justificante e exculpante) e a reforma dos dispositivos penais.

${ }^{14}$ Redação antiga do Código Penal alemão, §52: "No existe acción punible, si el autor ha sido obligado a la acción por medio de una amenaza, la que estaba ligada con un peligro actual, no evitable de otra manera, para el cuerpo o vida de sí mismo o de un pariente"; já o antigo §54 do mesmo código, rezava que "no existe acción punible, si la acción, además del caso de legítima defensa, ha sido cometida en un estado de necesidad no culpable, no removible de otra manera, para la salvación de un peligro actual para el cuerpo o la vida del autor o de un pariente". Cf. apêndice "códigos y proyectos de códigos citados en el texto" da obra GOLDSCHMIDT, James. La Concepción Normativa de la Culpabilidad. Tradução de Margarethe de Goldschmidt e Ricardo C. Núnez. 2a edição. Buenos Aires: Editorial B de F, 2002. Atualmente, o estado de necessidade está regulado nos artigos §34 e §35 do CP alemão, e a legítima defesa no $§ 32$ e $\S 33$.

15 WELZEL, Hans. O Novo Sistema Jurídico Penal: uma introdução à doutrina da ação finalista. Tradução de Luiz Regis Prado. 2a Edição. São Paulo: RT, 2010, p. 154. 16 TOLEDO, Francisco de Assis. Princípios Básicos do Direito Penal. São Paulo: Saraiva, 2008, p. 177. 
É digno de nota, contudo, que WELZEL já trata do referido dispositivo (§54) como causa de exclusão da culpabilidade (estado de necessidade exculpante), especificando as situações nas quais ocorria a lesão para salvaguarda da vida ou integridade física do autor sem que a ação estivesse justificada. Buscando o assunto na obra de WESSELS ${ }^{17}$, tem-se a confirmação de que o antigo §54 do CP alemão tratava, como bem afirmou WELZEL, da previsão do estado de necessidade exculpante, hoje elencado no §35, I da mesma legislação. Não se pode dizer, portanto, como o faz ASSIS TOLEDO, que o estado de necessidade exculpante teria sido admitido na legislação alemã apenas com a incorporação dos novos $\S \S 34$ e 35, mas é certo que, com esses dispositivos, passou-se a admitir a diferenciação entre ambos os estados de necessidade no que tange à ponderação de bens em conflito, já que os novos dispositivos abordam, ao contrário dos artigos revogados, a condição dos bens jurídicos afetados com a conduta, e é justamente a prevalência dos interesses protegidos sobre os prejudicados com a conduta que diferencia a ação justificada da desculpada ${ }^{18}$.

${ }^{17}$ WESSELS, Johannes. Direito penal. Parte geral (aspectos fundamentais). Tradução do original alemão e notas por TAVARES, Juarez. Porto Alegre: Sergio Antonio Fabris Editor, 1976, p. 89 e s.

${ }^{18}$ Já transcritos, em nota de rodapé n. 14, os dispositivos dos antigos $§ \S 52$ e 54 do Código Penal alemão, urge trazer, para comparação, os novos dispositivos dos $\S \S 34$ e 35, em comprovação às assertivas trazidas no corpo do texto: "§ 34 . Estado de necesidad justificante: Quien en un peligro actual para la vida, el cuerpo, la libertad, el honor, la propiedad u otro bien jurídico no evitable de otra manera, cometa un hecho con el fin de evitar un peligro para sí o para otro, no actúa antijurídicamente si en la ponderación de los intereses en conflicto, en particular de los bienes jurídicos afectados, y de su grado del peligro amenazante, prevalecen esencialmente los intereses protegidos sobre los perjudicados. Sin embargo, esto rige solo en tanto que el hecho sea un medio adecuado para evitar el peligro" / '\$35. Estado de necesidad disculpante: (1) Quien en un peligro actual para la vida, el cuerpo o la libertad no 
Em obra publicada no ano de 1922, FREUDENTHAL já descrevia alguns casos submetidos à análise do Tribunal Supremo Alemão, referindo-se ao julgamento que absolveu um pai da acusação de não promover o socorro de sua filha doente a um hospital, omissão adotada em razão do conflito de obrigações éticas em atender aos pedidos da menina e de sua mulher, manifestados no leito de morte desta última, sempre com o intuito de causar menos sofrimento à criança com a submissão ao tratamento médico ${ }^{19}$.

Um outro interessante exemplo de julgado, também referido por esse autor alemão, trata de caso semelhante ao do cocheiro que sela o cavalo de caça. O caso é ocorrido com o capitão de um barco

evitable de otra manera, cometa un hecho antijurídico con el fin de evitar el peligro para él para un pariente o para otra persona allegada, actúa sin culpabilidad. Esto no rige en tanto que al autor se le pueda exigir tolerar el peligro, de acuerdo con las circunstancias particulares, porque el mismo ha causado el peligro o porque el estaba en una especial relación jurídica. Sin embargo, se puede disminuir la pena conforme al § 49 inciso l., cuando el autor no debería tolerar el peligro en consideración a una especial relación jurídica. (2) Si el autor en la comisión del hecho supone erróneamente circunstancias que a él lo puedan exculpar conforme al inciso primero, entonces sólo será castigado cuando el error hubiese podido evitarse. La pena ha de atenuarse conforme al $\S 49$, inciso 1". Cf. Código Penal alemão, traduzido para a língua espanhola.

Disponível

em: $<$ http://juareztavares.com/textos/leis/cp_de_es.pdf $>$. Acesso em: 03.12.2011.

${ }^{19}$ Nesse caso, o Tribunal parte do entendimento de que a omissão do objetivamente necessário, mesmo sendo assim reconhecido, não fundamenta uma violação ao dever inerente à culpa, já que o pai estava em conflito de obrigações éticas, “a pesar de su mejor voluntad de obrar en pro del bienestar del niño, no ha podido tomar a tempo la decisión correcta sólo a causa de su propia falta de las deseables determinación firme y energía". O Tribunal negou, então, a existência da "culpabilidade culposa", já que considerações morais, associadas à indecisão do autor, tornaram impossível a ele a observância da norma. FREUDENTHAL, Berthold. Culpabilidad y Reproche en el Derecho Penal. Tradução e prólogo de José Luis Guzmán Dalbora. Buenos Aires: Editorial B de F, 2003, p. 80. 
cargueiro de pólvora, que, após descarregar o material na fábrica, pretendeu lavá-lo antes de receber um novo embarque. No entanto, o gerente da fábrica o ordenou que regressasse imediatamente ao rio para atender a um rebocador que acabara de chegar, recebendo a carga sem efetuar a limpeza da carga anterior, de pólvora. A ordem foi mantida mesmo após o barqueiro alertar o patrão dos riscos de um incêndio no barco, oportunidade em que o barqueiro foi ameaçado de cancelamento de seu contrato caso não obedecesse as ordens daquele. O navio veio a explodir após uma combustão espontânea, tendo o Tribunal julgador entendido que não se podia exigir do capitão do barco que deixasse sem cumprimento a ordem do agente da fábrica, evitando o resultado que havia previsto, e aceitar a perda do emprego do qual dependia sua subsistência ${ }^{20}$. Todos esses exemplos tratavam de hipóteses de conflitos de deveres e/ou interesses.

É em análise aos dispositivos legais já previstos no direito alemão, bem como à ideia de ponderação de interesses, presente nos julgados dos Tribunais, que WELZEL passa a admitir e desenvolver hipóteses para aceitação das dirimentes supralegais.

Inicialmente, afirma esse autor que o estado de necessidade penal ali elencado, como excludente de culpabilidade, baseia-se na ideia de que, em uma tal situação de perigo, a obediência ao direito demandaria do autor um sacrifício tão grande que a conduta jurídica não poderia lhe ser exigida, em atenção ao instinto humano de conservação. Aduz que, embora os mencionados dispositivos limitem a hipótese de exclusão da culpabilidade às situações nas quais o próprio autor ou seus parentes próximos se encontrassem naquelas situações

20 FREUDENTHAL, Berthold. Culpabilidad y Reproche en el derecho penal. Tradução e prólogo de José Luis Guzmán Dalbora. Buenos Aires: Editorial B de F, 2003, p. 82. 
de perigo (antigos $\S \S 52$ e 54), haveria outras situações nas quais o autor também se encontraria ante um conflito de deveres ou conflito de consciência, muito embora não relacionado à sua vida ou integridade, bem como vida e integridade de seus parentes ${ }^{21}$. Estava WELZEL admitindo, portanto, que as hipóteses legais não contemplavam necessariamente todas as hipóteses reais.

Assim, WELZEL desenvolveu um modelo para o reconhecimento das causas de exculpação fora dos limites legais, baseado na dirimente do estado de necessidade exculpante, verificada quando o bem sacrificado na situação de risco é de maior valor do que o salvaguardado (fato que afastaria a aplicação do estado de necessidade como excludente da antijuridicidade $)^{22}$. O clássico exemplo welzeliano de inexigibilidade de conduta diversa, baseado na jurisprudência alemã, é o reconhecimento da incensurabilidade da conduta dos médicos que praticaram a eutanásia determinada pelo regime nazista. Muito embora os médicos tenham se utilizado da morte de pessoas inocentes para, na verdade, proteger outras vidas, não havia de se negar a tipicidade e antijuridicidade das suas condutas. Apesar de delineados tais elementos do crime, expõe WELZEL, para o caso mencionado, que o ordenamento, sem embargo, não pode formular uma reprovabilidade ao agente por ter ele praticado um injusto menor para proteger e evitar um injusto maior (a morte de mais pacientes), devendo ser dispensada a indulgência, já que qualquer outro cidadão no lugar do autor tenderia a agir exatamente do mesmo modo ${ }^{23}$.

${ }^{21}$ WELZEL, Hans. O Novo Sistema Jurídico Penal: uma introdução à doutrina da ação finalista. Tradução de Luiz Regis Prado. 2a Edição. São Paulo: RT, 2010, p. 155. ${ }^{22}$ Idem. Derecho Penal Aleman. Tradução de Juan Bustos Ramírez y Sergio Yáñez Perez. 11ª edição. Santiago de Chile: Editorial Jurídica de Chile, 1997, p. 217.

23 "El ordenamiento, sin embargo, no le puede formular un reproche de culpabilidad por haber asumido lo injusto menor para proteger de lo injusto mayor. Tiene que 
Outro exemplo trazido pelo autor alemão é o caso do médico que retira a máscara cardiopulmonar de um paciente gravemente ferido, para ceder a outro, cujas chances de sobrevivência são maiores. Quando o primeiro paciente vem a falecer, defende-se que o ato do médico também não poderia, dada a situação, ser reprovado.

Vê-se, dos dois exemplos mencionados, que as hipóteses a ensejar a dirimente extra legal eram, à época, limitadas a situações de conflito de deveres, nos quais se teria de realizar a opção de preservação de um bem jurídico em detrimento de outro. Nesse quadro fático e jurídico, WELZEL definiu, como pressupostos para reconhecimento das causas supralegais de exculpação:

(a) Que a ação do autor era o único meio para evitar uma desgraça maior;

(b) Que o autor elegeu realmente o mal menor, e

(c) Que ele perseguiu subjetivamente a finalidade de salvação ${ }^{24}$.

Não pode passar despercebido que as hipóteses firmadas pelo autor coincidiam com os poucos casos apreciados pelo Tribunal alemão à época, todos intimamente relacionados a situações de conflito de deveres.

dispensar indulgencia, porque cualquier otro ciudadano en el lugar de autor tendría que haber actuado exactamente del mismo modo que el autor". WELZEL, Hans. Derecho Penal Aleman. Tradução de Juan Bustos Ramírez y Sergio Yáñez Perez. 11a edição. Santiago de Chile: Editorial Jurídica de Chile, 1997, p. 217.

${ }^{24}$ WELZEL, Hans. Derecho Penal Aleman. Tradução de Juan Bustos Ramírez y Sergio Yáñez Perez. 11ạ edição. Santiago de Chile: Editorial Jurídica de Chile, 1997, p. 217218. 
Era possível, então, reconhecer-se uma exculpação supralegal, desde que a conduta eleita pelo agente fosse o único meio de se evitar uma desgraça maior, que o autor da conduta realmente tivesse buscado o mal menor e que sua intenção fosse relacionada a fins de salvação.

Ante o exposto, tem-se que, para WELZEL, na primeira metade do séc. XX e dispondo da jurisprudência do Tribunal alemão, as causas de não exigibilidade supralegal se caracterizavam como uma extensão do estado de necessidade exculpante. Não se vislumbravam, à época, novos e diferentes delineamentos.

Mais recentemente, ao dissertar acerca das hipóteses de não exigibilidade presentes no Direito Penal Alemão, CLAUS ROXIN ${ }^{25}$ ressalta que, além do estado de necessidade exculpante e do excesso da legítima defesa, ambos previstos no Código Penal alemão (atuais artigos $\S 33$ e $\S 35)^{26}$, o Tribunal Constitucional Federal daquele país

${ }^{25}$ ROXIN, Claus. Derecho Penal. Parte General, Tomo I. Tradução e notas de DiegoManuel Luzón Peña, Miguel Diaz y Garcia Conlledo e Javier de Vicente Remesal. Madrid: Editorial Civitas, 2007 (reimpressão da 2a edição alemã, 1997). Pág. 942-943. ${ }^{26}$ Enquanto o §34 do prevê o estado de necessidade justificante, o §35 trata do exculpante, seguindo a teoria diferenciadora do estado de necessidade. ROXIN, no entanto, esclarece que o caso do estado de necessidade exculpante, apesar do sujeito eximir-se da pena, não implica a falta de desaprovação de seu ato pelo ordenamento jurídico, mas sim que sua conduta, em que pese a desaprovação, não se julga necessitada de aplicação da pena. Acrescenta o autor que o uso da linguagem da lei (ao falar em exclusão da culpabilidade) é impreciso já que o §35 não exclui a culpabilidade no sentido estrito da palavra, mas sim a responsabilidade jurídico penal, "pues el §35 sólo posee trascendencia práctica cuando el amenazado era aún asequible a la norma y habría podido actuar de otro modo, de manera que existe una culpabilidad (aunque sea notablemente reducida)". ROXIN, Op. Cit., p. 897. Em acréscimo, esclarece ROXIN que o §33 se trata de uma causa de exculpação na qual o sujeito que se excede se comporta culpavelmente, ainda que com culpabilidade 
acata as hipóteses de (a) desobediência civil e (b) o fato realizado por motivo de consciência, que, embora não tenham previsão na lei penal, têm sua base no art. 4 GG (Lei Fundamental da República Federal da Alemanha).

Interessante frisar que esse autor alemão se posiciona contra a adoção das causas supralegais de inexigibilidade. No entanto, as duas formas de exclusão da responsabilidade acima apontadas teriam para ROXIN fundamento diverso, derivados da Constituição alemã.

As causas exculpantes expressamente previstas no Código Penal alemão seriam o estado de necessidade exculpante do $\S 35$, o excesso de legítima defesa do $\S 33$ e, na parte especial, a omissão de denúncia contra parentes $(\S 139, \mathrm{III}, 1)^{27}$, o incesto entre menores de idade ( $\S 173, \mathrm{III})$ e o favorecimento pessoal ou frustração da pena em proveito de outrem quando se pretende evitar uma pena a si mesmo $(\S 258, \mathrm{~V})$ ou a um parente $(\S 258, \mathrm{VI})^{28}$. Fora dessas hipóteses, a

reduzida, e o legislador renuncia a punição porque a pena não se torna necessária para fins de prevenção especial ou prevenção geral (p. 927).

${ }^{27}$ Estaria isenta de pena a omissão em denunciar determinados delitos praticados por parentes se o indivíduo esforçara-se, de todo modo, a evitar o cometimento do crime ou evitar o seu resultado. O conflito do dever de denunciar e a solidariedade com os parentes diminuiria a liberdade de decisão do agente, sem suprimi-la, e os esforços anteriores do agente o mostram como uma pessoa fiel ao Direito, que não precisaria da intervenção penal. ROXIN, Claus. Derecho Penal. Parte General, Tomo I. Tradução e notas de Diego-Manuel Luzón Peña, Miguel Diaz y Garcia Conlledo e Javier de Vicente Remesal. Madrid: Editorial Civitas, 2007 (reimpressão da 2a edição alemã, 1997), p. 955-956.

${ }^{28}$ Não se castiga por favorecimento pessoal ou frustração da pena quem, com esse fato, pretende evitar que outra pena lhe seja dirigida; não se obriga o sujeito a colocar a corda no próprio pescoço. No caso de favorecimento a um parente, concorre a situação de conflito interno que dificulta a motivação do agente, com a circunstância de que a punição a esse agente não parece imprescindível à prevenção, já que quem 
possibilidade de exculpação estaria vinculada a permissões de direitos fundamentais, através das modalidades de (a) a desobediência civil e (b) o fato realizado por motivo de consciência.

Já o Código Penal Espanhol prevê duas hipóteses de isenção de pena pela inexigibilidade de conduta diversa: o medo insuperável e o favorecimento entre parentes ${ }^{29}$.

$\mathrm{O}$ estado de necessidade entre bens de igual valor, previsto no art. 20, número 5․ do Código Penal espanhol, apresenta uma problemática específica, discutindo os autores se se trata de estado de necessidade justificante ou exculpante. Pela própria descrição do dispositivo penal espanhol ${ }^{30}$, no entanto, vê-se se tratar de estado de necessidade justificante, já que a condição "que el mal causado no sea mayor que el que se trate evitar" (ou seja, aceita-se, no conflito de bens, o sacrifício de bens de valor menor e igual ao protegido) é elencada junto às outras condições do estado de necessidade, dentre elas a de que a situação de necessidade não tenha sido provocada intencionalmente pelo sujeito e que ele não tenha, por seu ofício ou cargo, o dever de enfrentar o perigo. Não há porque admitir-se, assim, a diferenciação entre o estado de necessidade exculpante para

frustra a pena em proveito de um parente não se mostra de todo hostil ao Direito. ROXIN, Op. Cit., p. 957.

${ }^{29}$ Cf. MUÑOZ CONDE, Francisco; GARCIA ARÁN, Mercedes. Derecho Penal: Parte general. Valencia: Tirant lo Blanch, 2010, p. 388.

${ }^{30}$ Código Penal espanhol: “Artículo 20. Están exentos de responsabilidad criminal: (...) 5․ El que, en estado de necesidad, para evitar un mal propio o ajeno lesione un bien jurídico de otra persona o infrinja un deber, siempre que concurran los siguientes requisitos: Primero. Que el mal causado no sea mayor que el que se trate de evitar. Segundo. Que la situación de necesidad no haya sido provocada; intencionadamente por el sujeto; Tercero. Que el necesitado no tenga, por su oficio o cargo, obligación de sacrificarse”. Disponível em: $<$ http://www.juareztavares.com/textos/leis/cp_de_es.pdf>; Acesso em: 13.19.2011. 
sacrifício de bens de igual valor e o justificante para sacrifício de bens de menor valor ante a lei espanhola, já que o próprio legislador resolveu dar o mesmo tratamento a ambos, tratando-os de forma conjunta, no mesmo artigo e com os mesmos requisitos.

Deixando-se de lado as controvérsias sobre a previsão legal do estado de necessidade exculpante no direito espanhol, defende-se, em consonância com MUÑOZ CONDE, que o Código Penal espanhol trata como causa de não exigibilidade de conduta diversa apenas o miedo insuperable, do número 6o do artigo $20^{31}$, e o encubrimiento entre parientes, previsto no artigo 454 da mesma lei. Qualquer outra forma de exclusão da culpabilidade reconhecida pelos Tribunais daquele país se consubstanciaria em causa supralegal.

Para desenvolver o tema, a doutrina espanhola de MUÑOZ CONDE empreende minuciosa análise, em diversos artigos e capítulos específicos, sobre a delincuencia por convicción o por consciência. Já DE LA CUESTA AGUADO divide a possibilidade de reconhecimento da não exigibilidade supralegal em três níveis, todos adiante abordados.

Como já se afirmou, o Código Penal brasileiro prevê, na parte geral, apenas duas modalidades de causas de não exigibilidade (coação irresistível e obediência hierárquica).

Partindo da previsão do Código Penal brasileiro e dos modelos já desenvolvidos na doutrina estrangeira, CIRINO DOS SANTOS $^{32}$ divide as situações de exculpação supralegal no Brasil em quatro fórmulas, ou modelos, que compreendem (a) o fato de

\footnotetext{
31“Artículo 20. Están exentos de responsabilidad criminal: (...)6‥ El que obre impulsado por miedo insuperable. Disponível em: <http://www.juareztavares.com/textos/leis/cp_de_es.pdf>; Acesso em: 13.09.2011. ${ }^{32}$ CIRINO DOS SANTOS, Juarez. Direito Penal: Parte Geral. 2a ed. Curitiba: ICPC Editora Lúmen Iuris, 2007, p. 322-342.
} 
consciência, (b) a provocação da situação de legítima defesa, (c) a desobediência civil e (d) o conflito de deveres.

Passa-se a abordar, a partir desse momento, cada uma dessas quatro situações de exculpação supralegal para o direito brasileiro, empreendendo análise acerca da previsão das mesmas na legislação e doutrina comparadas para, ao final, acrescentar mais um novo modelo aos já trabalhados pela doutrina.

\section{A desobediência civil. Movimentos grevistas, ocupações rurais e urbanas, bloqueios em estradas e rebeliões em presídios}

A situação de exculpação definida como "desobediência civil" tem por objeto ações ou demonstrações públicas de bloqueios e ocupações realizadas em defesa do bem comum, ou de questões vitais da população, lutas coletivas em defesa de direitos, greves de trabalhadores, protestos, passeatas, etc. ${ }^{33}$ Os exemplos brasileiros são as invasões e bloqueios liderados pelo Movimento dos Trabalhadores Rurais Sem Terra (MST), as ocupações de prédios públicos organizadas pelo Movimento dos Trabalhadores Sem Teto (MTST), as rebeliões em presídios diante de situações de desrespeito aos direitos humanos e movimentos grevistas nos vários setores de trabalho.

É tida como uma forma particular de rebeldia, na medida em que é praticada visando a demonstração de uma injustiça da lei para induzir os legisladores a modificá-la ${ }^{34}$. Difere da desobediência comum porque objetiva, em última instância, a mudança do status quo, em geral para o bem coletivo.

${ }^{33}$ CIRINO DOS SANTOS, Juarez. Direito Penal: Parte Geral. 2a ed. Curitiba: ICPC Editora Lúmen Iuris, 2007, p. 339.

${ }^{34}$ DOTTI, René Ariel. Curso de Direito Penal: Parte geral. São Paulo: RT, 2010, p.514. 
Para a caracterização da exculpação, as condutas praticadas não devem estar vinculadas a ações ou manifestações violentas ou de resistência à ordem pública vigente, bem como apresentar relação reconhecível com os destinatários do movimento ${ }^{35}$.

A exculpação pode se basear na "existência objetiva de um injusto mínimo" e na "existência subjetiva de motivação pública ou coletiva relevante", ou na desnecessidade de punição, tendo em vista que os autores do comportamento não são voltados à prática de crimes (perdendo o sentido a retribuição da pena) e a solução de conflitos civis não se resolveria - muito pelo contrário - através do critério de prevenção geral e especial da pena ${ }^{36}$.

Seja qual for o fundamento utilizado, é fato que resta excluída a culpabilidade do agente, considerando que seu comportamento rebelde é tutelado por uma causa supralegal de não exigibilidade de conduta diversa. Exigir-se que o cidadão se cale, se omita ou se conforme com a violação de seus direitos por parte do próprio ordenamento jurídico não condiz com os ditames do Estado Democrático. A lei não pode exigir do indivíduo, pois, que acate o status quo que lhe é prejudicial para resguardar a manutenção da ordem social.

Afirma ROXIN que na desobediência civil - também não prevista expressamente no texto penal alemão, assim como não o é na legislação brasileira - a exclusão da responsabilidade não se consubstanciaria em causa de exculpação supralegal, mas estaria relacionada aos direitos fundamentais, já que as ações de protesto infratoras de regras, desde que guiadas pela preocupação de um bem comum, se encaixariam na proteção dos artigos 5 e 8 GG (Lei

\footnotetext{
${ }^{35}$ CIRINO DOS SANTOS, Juarez. Op. Cit., p. 339.

${ }^{36}$ CIRINO DOS SANTOS, Juarez. Op. Cit., p. 339-340.
} 
Fundamental da República Alemã), quando servem à formação da opinião pública em questões de interesse vital e não ameaçam ou apresentam dificuldades a nenhum outro interesse coletivo. Nesse caso, o sujeito não atuaria sem culpabilidade, a norma lhe era acessível e ele podia atuar de outro modo, mas tal culpabilidade se veria reduzida, e a pequena reprovabilidade não autorizaria a punição. Esse raciocínio deriva do fato de que, como já se disse, esse doutrinador alemão posiciona-se contra a admissão das exculpantes supralegais e elabora um conceito diferenciado de culpabilidade, relacionado à ideia de prevenção punitiva.

Como há a ponderação entre interesses individuais e coletivos na desobediência civil, ROXIN define, ainda, algumas restrições para o seu reconhecimento, quais sejam, (I) o protesto que acabou por infringir as normas deve referir-se a questões que interessem ao conjunto da população; (II) o sujeito deve atuar pelo bem comum; (III) a infração das regras deve mostrar uma conexão com o destinatário do protesto; (IV) o protestante deve declarar-se partidário da democracia parlamentar, ou seja, os revolucionários não poderiam ser absolvidos; (V) a desobediência civil deve evitar violência e resistência ativa às forças de ordem e, por fim, (VI) os impedimentos e infortúnios do protesto devem se manter reduzidos e limitados ${ }^{37}$.

É digno de nota que, mesmo já tendo por definido que os danos causados através dos protestos em defesa dos direitos coletivos não importariam em responsabilidade penal (em razão da tutela constitucional), ROXIN se empenhou em fixar requisitos à dirimente como forma de delimitar ainda mais a sua aplicação. Tal feito só denota

${ }^{37}$ ROXIN,Claus. Derecho Penal. Parte General, Tomo I. Tradução e notas de DiegoManuel Luzón Peña, Miguel Diaz y Garcia Conlledo e Javier de Vicente Remesal. Madrid: Editorial Civitas, 2007 (reimpressão da 2a edição alemã, 1997), p.953-955. 
a efetiva preocupação da doutrina na fixação dos parâmetros de aplicação da excludente de culpabilidade nos casos não previstos em lei, refutando qualquer alegação de que a adoção dessa exculpante supralegal representaria insegurança ou incerteza jurídicas.

Em abril de 2013 o Tribunal de Justiça de São Paulo julgou a situação de detentos que, cumprindo pena socioeducativa, resolveram atear fogo em colchões no intuito de serem ouvidos sobre as suas críticas ao local e conseguirem transferência para outra unidade. Haviam sido condenados, em primeiro grau, pelo crime de incêndio ${ }^{38}$. Analisando o recurso de apelação, no qual se alegou a excludente supralegal de culpabilidade em razão da desobediência civil - amparada nas reinvindicações dos detentos, que poderiam ser reputadas como legítimas - o Tribunal paulista entendeu não estarem presentes os requisitos da desobediência civil ou de um "direito de resistência”, considerando a violência e o risco representados pela conduta dos acusados. Interessante consignar que, em manifestação no processo, o Ministério Público utilizou-se do entendimento já outrora esclarecido que refuta a aceitação das causas supralegais de inexigibilidade de conduta diversa, tendo-a como um critério vago e indeterminado, que não poderia ser admitido como princípio jurídico. Independentemente do caso concreto ali analisado, cujas conclusões seguem transcritas, é patente a dificuldade de alguns operadores do direito em admitir o julgamento supralegal. Entende-se, contudo, que a simples discussão sobre o cabimento ou não da desobediência civil nas esferas do Judiciário (e da caracterização de

38 Por não poder se referir à prática de crimes por menores de idade, e sim ato infracional, e considerando que o acórdão em comento refere-se à terminologia "crime" e às penas e tipificação do Código Penal, conclui-se que os réus na ação penal se tratavam de maiores de 18 anos cumprindo o término de penas sócio educativas aplicadas quando ainda eram menores de idade. 
seus requisitos no caso concreto) já fomenta o uso dessa causa supralegal:

"Ao que tudo indica, como forma de reinvindicação, eles, no intuito de obterem suas transferências para outra unidade, acabaram ateando fogo no colchão do quarto de número dez, da ala B, onde instalados estavam, expondo a perigo a vida e a integridade física deles, bem como a de terceiros. No entanto, o fogo foi contido por agentes de apoio daquela ala, que tomaram as providências necessárias, neste sentido. Diante disso, fora registrado um boletim de ocorrência e instaurado o Inquérito Policial, mediante portaria (cf. fls.02 e 03/06)

(...)

Eles, perante a autoridade policial, admitiram os fatos; alegando terem assim agido para reivindicar suas transferências para outra unidade. Em juízo, mantiveram as confissões. De certa forma, declararam-se arrependidos, diante da afirmação de que a vida no CDP de Guarulhos, para onde foram transferidos, teria se tornado mais difícil. Jeferson chegou a admitira forma errônea e perigosa de tais condutas (cf. fls. 15, 20, 25 e 239CD). Suas versões forneceram a certeza necessária de suas culpabilidades.

\section{(...)}

Bem demonstradas a autoria e materialidade do crime de incêndio. E, contrariamente ao alegado, as circunstâncias dos fatos e as provas colacionadas ao processo comprovaram, satisfatoriamente, $o$ risco patente pelos réus causado a si e a 
indeterminado número de pessoas que ali se achavam, no interior da Fundação Casa, sita em um prédio público (cf. laudo pericial, às fls. 229/237). Portanto, outro não poderia ser o desfecho, senão o condenatório.

Não se há falar em desobediência civil, onde uma grave injustiça é combatida com uma resposta justa e proporcional; pois aqui os agentes atuaram de forma violenta, expondo a risco a vida deles e de outros jovens infratores; não para combaterem uma grave injustiça; mas, sim, para satisfazerem seus egoísticos desejos de se verem transferidos para outra unidade. Evidente que seus dolos eram o de provocar um incêndio, na proporção que fosse e não o de causarem dano. Eles próprios admitiram isso. Portanto, inviável a desclassificação para dano qualificado.

Ainda, no tocante a tese de causa supralegal da excludente de culpabilidade, de desobediência civil e ou de direito de resistência, neste sentido, fora esclarecedor o parecer do insigne Procurador de Justiça, às fls.289/290: "Data vênia da tese principal alegada, embora hoje haja uma tendência a admitir excepcionalmente a presença desse tipo de causa supralegal, estaríamos diante da denominada inexigibilidade de conduta diversa, a qual se situa no Direito Penal, na teoria da culpabilidade. De acordo com a concepção normativa, a culpabilidade é excluída toda a vez que não se pode exigir do agente uma conduta diferente daquela realizada. É o caso das hipóteses de coação moral irresistível e da obediência hierárquica de ordem não manifestamente ilegal (art. 22 do Código Penal). Em 
outras situações há de ter-se extremo cuidado quanto à aplicação desse instituto eis que a própria doutrina tradicional brasileira vislumbra na inexigibilidade de conduta diversa um critério vago e indeterminado, que não pode ser admitido como princípio jurídico nem aplicado fora das hipóteses previstas em lei."(TJSP - Apelação 000144146.2012.8.26.0050 / Relator(a): Cardoso Perpétuo / Comarca: São Paulo / Órgão julgador: 13a Câmara de Direito Criminal / Data do julgamento: 11/04/2013 / Data de registro: 16/04/2013 / Outros números: 14414620128260050).

\section{Fato de consciência ou delinquência por convicção}

O fato de consciência, segundo a doutrina de CIRINO DOS SANTOS, tem por objeto decisões morais ou religiosas representativas de deveres incondicionais vinculantes da conduta, "asseguradas pela garantia constitucional de liberdade de crença e de consciência" e limitadas, apenas, por outros direitos fundamentais individuais ou coletivos, mas não pela lei penal ${ }^{39}$. Corresponderia à delincuencia por convicción o por conciencia tratada por MUÑOZ CONDE, ou ao fato realizado por motivo de consciência, de CLAUS ROXIN ou, ainda, ao dissenso normativo da doutrina de DE LA CUESTA AGUADO.

${ }^{39}$ CIRINO DOS SANTOS, Juarez. Direito Penal: Parte Geral. $2 \underline{a}$ ed. Curitiba: ICPC Editora Lúmen Iuris, 2007, p.337. 
Por se tratar de causa de exculpação não prevista na legislação espanhola, a doutrina de MUÑOZ $\mathrm{CONDE}^{40}$ desenvolveu minuciosa abordagem à chamada delincuencia por convicción o por conciencia, constituída através de uma valoração diferente elaborada pelo indivíduo frente à valoração do fato pretendida pela norma: ainda que o agente conheça a proibição, não lhe reconhece eficácia para motivar, através dela, seus atos. O exemplo mencionado pelo próprio autor relaciona-se à negativa de transfusão de sangue por adeptos da religião Testemunhas de Jeová (o que poderia vir a comprometer a saúde do paciente).

Em suas obras, o autor espanhol se atém ao estudo do tema, fundamentando e exemplificando o que entende por delinquência por convicção. Explica que, em uma sociedade democrática e plural, tornase inevitável um certo grau de discrepância e de rebeldia do indivíduo frente a uma norma concreta ou a um setor do Ordenamento Jurídico, discrepância que se deve a conflitos de consciência ${ }^{41}$. É o caso do agente que tem uma atitude valorativa diferente daquela contida na norma infringida e, ainda que reconheça o âmbito proibitivo da norma, não lhe reconhece eficácia motivadora de seus atos ${ }^{42}$. É de se registrar que muitas vezes o conflito de consciência evidencia uma ausência de legitimação da própria norma infringida, já que muitas vezes a formulação de um tipo nem sempre representa um conflito entre o agente e a sociedade, mas entre distintos sistemas sociais e distintas formas de entender a vida. Assim, pontua MUÑOZ CONDE

${ }^{40}$ MUÑOZ CONDE. La Objeción de Conciencia en Derecho Penal. In: Nova Doutrina Penal NDP 96/A, pg. 87-102. Disponível em: $<$ http://www.pensamientopenal.com.ar/ndp/ndp005.htm>;Acesso em: 12.05.2010. ${ }^{41}$ MUÑOZ CONDE, Francisco; GARCIA ARÁN, Mercedes. Derecho Penal: Parte general. Valencia: Tirant lo Blanch, 2010, p. 393.

${ }^{42}$ Idem, ibidem, p. 393. 
que o que caracteriza uma sociedade democrática e pluralista é a possibilidade de coexistência pacífica desses distintos sistemas de valores, baseados em razões religiosas, morais e políticas, os quais, às vezes, são tidos por contraditórios ${ }^{43}$.

Outro exemplo dessa situação (além do clássico exemplo da transfusão de sangue) é a recusa do médico em realizar o aborto na gestante que corre sério risco de vida, não concordando em retirar a vida do feto por razões religiosas ou morais, mesmo que tal ato implique na efetiva lesão à vida ou saúde da gestante.

Esclarece a doutrina de CIRINO DOS SANTOS que o fato de consciência constitui a experiência existencial de um sentimento interior de obrigação incondicional, cuja proteção constitucional impediria sua valoração como "certo" ou "errado", devendo ser verificado tão somente o poder do mandamento moral ou religioso à personalidade do agente. Seguindo a linha de raciocínio de ROXIN, aduz o autor brasileiro que essa dirimente seria amparada na norma constitucional que tutela a liberdade de crença e a manifestação de pensamento ${ }^{44}$.

Na realidade, explicou o autor alemão que, como decisão relacionada ao "motivo de consciência" se há de entender toda decisão moral orientada pelas categorias de "bom" ou "mau" que o indivíduo experimenta de forma interior, em uma determinada situação que, para ele, tornou-se vinculante ou incondicionalmente obrigatória "de modo que no podría actuar en contra de ella sin cargo o conflicto serio de conciencia”. Assim, a valoração jurídico penal do fato realizado por motivo de consciência deve derivar do próprio artigo 4 GG da

\footnotetext{
${ }^{43}$ Idem, ibidem, p. 393.

${ }^{44}$ CIRINO DOS SANTOS, Juarez. Direito Penal: Parte Geral. 2a ed. Curitiba: ICPC Editora Lúmen Iuris, 2007, p. 337.
} 
Constituição alemã, que reza serem invioláveis a liberdade de crença e de consciência. Nesse raciocínio, um fato realizado por motivo de consciência deve resultar necessariamente impune quando seu castigo atentaria contra a liberdade constitucionalmente assegurada, considerando, ainda, que o mencionado dispositivo constitucional tem efeito imediato no direito vigente e maior hierarquia do que as normas penais ${ }^{45}$.

Explica ROXIN que a decisão de consciência não pressupõe uma determinada qualidade quanto a seu conteúdo, cabendo ao Juiz examinar apenas se essa decisão possui verdadeiramente um caráter de "imperativo moral irredutível", ou seja, a seriedade de um imperativo moral que domina a personalidade do agente para fazê-lo descumprir a norma. Por outro lado, tal decisão não pode ser valorada como equivocada, errada, ou correta, o que iria vulnerar a neutralidade ideológica do Estado e anular a liberdade de decisão de consciência em favor de uma determinada ideologia ou crença ${ }^{46}$.

Faz-se um parêntese para registrar, novamente, que, em sendo ROXIN contrário à adoção das causas supralegais de exclusão da culpabilidade, como já se afirmou, esse autor trata de esclarecer que o fato realizado por motivo de consciência fundamenta-se em uma "causa extrapenal" mas não "supralegal" de exclusão da responsabilidade, pois tal exculpação, como já se afirmou, seria baseada no artigo 4 da Constituição alemã ${ }^{47}$. Da mesma forma que no caso da desobediência civil, não se trataria de uma questão de culpabilidade, mas de responsabilidade: não se trataria do debate se o sujeito poderia

\footnotetext{
${ }^{45}$ ROXIN, Claus. Derecho Penal. Parte General, Tomo I. Tradução e notas de DiegoManuel Luzón Peña, Miguel Diaz y Garcia Conlledo e Javier de Vicente Remesal. Madrid: Editorial Civitas, 2007 (reimpressão da 2a edição alemã, 1997), p. 942 e 943. ${ }^{46}$ Idem, ibidem, p. 943.

${ }^{47}$ Idem, ibidem, p. 961.
} 
atuar de outro modo, mas se sua atuação antijurídica precisaria de pena. A despeito desse posicionamento, mesmo restando claro que ROXIN é contrário à adoção da não exigibilidade como causa supralegal de exclusão da culpabilidade, impende, pela relevância do tema, o registro de sua tentativa de legitimar, ainda que sob diverso fundamento (a derivação da norma constitucional alemã), a aplicação do "motivo de consciência" e da "desobediência civil".

Pois bem. Uma interessante observação é trazida por JUAREZ CIRINO DOS SANTOS quando analisa o conhecido exemplo dessa causa exculpante, a recusa do pai à transfusão de sangue de um filho menor. Esclarece CIRINO DOS SANTOS que no caso de tipos penais que protegem direitos humanos fundamentais, tal exculpação é condicionada à existência de uma alternativa neutra que dê efetiva proteção ao bem jurídico tutelado pela norma, ou seja, com a negativa do genitor por motivos religiosos, uma ação do médico movida por estado de necessidade ou uma determinação do Conselho Tutelar supririam a recusa, de forma que "em nenhuma hipótese o fato de consciência exculpa a efetiva lesão de bens jurídicos individuais fundamentais" ${ }^{48}$. É de se ver, no entanto, que no caso de a recusa motivada por fato de consciência ser facilmente suprível e inocorrer a lesão, sequer se haveria de falar em conduta típica, ante a ausência de ofensividade na conduta a causar lesão no bem jurídico tutelado ${ }^{49}$.

${ }^{48}$ CIRINO DOS SANTOS, Juarez. Direito Penal: Parte Geral. 2a ed. Curitiba: ICPC Editora Lúmen Iuris, 2007, p. 337.

${ }^{49} \mathrm{~A}$ doutrina penal alerta para algumas incoerências do direito ao tipificar condutas incapazes de ofender a bens jurídicos, apontando algumas vezes construções deontológicas perfeitas, mas inadequadas a aplicações concretas. Assim, tanto é possível uma conduta ofender determinado bem jurídico relevante e não ser sancionada pela lei penal (como determinados crimes de informática, ainda não regulados), como pode ocorrer a adequação do comportamento à letra da lei e tal 
Como é óbvio, um pai que recusasse a transfusão sanguínea de um filho, sabedor de que essa transfusão seria realizada de qualquer forma, mesmo sem seu consentimento, não pode ter sua conduta sequer enquadrada nas normas típicas, a ensejar uma posterior exculpação, simplesmente porque sua conduta, ineficiente a causar lesão, representou apenas a manifestação de seu pensamento e crença, sem consequência penal.

A própria doutrina de CIRINO DOS SANTOS reconhece que a matéria é controvertida, aduzindo que o fato de consciência, "por um lado, exclui a tipicidade, se existe alternativa neutra de proteção do bem jurídico"50.

O raciocínio utilizado por CIRINO DOS SANTOS condicionando $\mathrm{a}$ isenção de pena à proteção concreta do bem jurídico através de uma alternativa neutra, no caso de possibilidade de ofensa a bens jurídicos fundamentais, também foi desenvolvido por MUÑOZ CONDE, ao explicar que, quando o bem jurídico ameaçado pela delinquência por convicção classifica-se como bem jurídico individual (vida, integridade, liberdade e propriedade), não se pode dar nenhuma relevância à decisão de consciência que o viole, já que aqueles bens jurídicos seriam mais importantes do que a liberdade de consciência

comportamento não se revelar materialmente ofensivo ao bem jurídico protegido pela norma. Para resolver a antinomia, alguns autores vêm se firmando pela necessidade da adequação da conduta ao conceito material (e não simplesmente formal) de delito. Não bastaria, pois, para a caracterização do delito, que o sujeito realizasse formalmente a descrição legal, mas que afetasse o bem jurídico por trás do enunciado legal, que ofendesse a essência da norma valorativa, tendo-se que "a tipicidade não se esgota na adequação literal ou gramatical da conduta, sendo mister, sempre, o plus da afetação concreta do bem jurídico (delito em sentido material)". Cf. GOMES, Luiz Flávio. Princípio da ofensividade no Direito Penal. São Paulo: Revista dos Tribunais, 2002, p. 114.

${ }^{50}$ CIRINO DOS SANTOS, Op. Cit., p. 338. 
constitucionalmente abalizada ${ }^{51}$. Assim, não só os casos de terrorismo político, mas os rituais de assassinatos praticados dentro de uma seita, ou a objeção de consciência fanática que acaba por deixar morrer, sem assistência, uma mulher que sofre as sequelas de um aborto ilegal, devem estar fora de toda consideração exculpatória, até mesmo a atenuante ${ }^{52}$.

Conjugando o entendimento dos autores, só haveria exculpação quando o bem jurídico atingido fosse de menor importância e não houvesse, naquele caso específico, uma solução alheia, de terceira pessoa, que neutralizasse a delinquência do indivíduo. Isso porque, como já se disse, nesses últimos casos não haveria ofensa alguma ao bem jurídico. Mas e quando ocorre de o genitor, da religião Testemunha de Jeová, por exemplo, negar a autorização da transfusão sanguínea de seu filho, por fato de consciência, e o dano realmente ocorrer, ou seja, a intervenção neutra do médico não se fazer presente? Quem responde pelo crime de homicídio do menor que não foi, a tempo, submetido ao tratamento médico adequado? O genitor terá o benefício da exculpação, mesmo se percebendo que o bem jurídico atingido (vida) tem maior relevância do que a tutela da liberdade de crença? O médico será responsabilizado porque não agiu a tempo, independentemente da autorização negada?

Para estudar as indagações acima, volta-se a um caso hipotético. Imagine-se uma criança convalescente no hospital precisando da autorização dos pais, adeptos da religião Testemunha de Jeová, para realizar um procedimento de emergência que implique na

\footnotetext{
${ }^{51}$ MUÑOZ CONDE, Francisco; GARCIA ARÁN, Mercedes. Derecho Penal: Parte general. Valencia: Tirant lo Blanch, 2010, p. 394.

${ }^{52}$ MUÑOZ CONDE, Francisco; GARCIA ARÁN, Mercedes. Op. Cit., p. 394.
} 
transfusão sanguínea. Os médicos alertam os pais do risco ao qual a criança será submetida, caso não seja feita a transfusão. Os pais estão irredutíveis, já que a religião entende que após a transfusão a pessoa passa a ser considerada impura ${ }^{53}$. Outro médico, também fiel da mesma religião, corrobora com a opinião dos pais, que acabam por refutar o tratamento médico sugerido e negam a autorização de transfusão. Apenas tratamentos paliativos são ministrados, e a criança vem a óbito.

Há dois grupos a serem responsabilizados: os pais e o médico religioso, que não permitiram o tratamento adequado e exigível; e os médicos que sugeriram a transfusão de sangue e não a realizaram por falta de autorização dos pais da criança.

$\mathrm{O}$ caso descrito foi submetido a julgamento perante o Tribunal de Justiça do Estado de São Paulo, em dezembro de 2010, oriundo de processo criminal da Comarca de São Vicente/SP. Foram denunciados por homicídio doloso os genitores da vítima, que se negaram a autorizar a transfusão sanguínea, e o médico religioso que os apoiou nessa decisão a despeito do diagnóstico alertado por todos os outros médicos do hospital que cuidavam do caso.

Os acusados foram pronunciados pelo crime de homicídio, e entraram com recurso em sentido estrito da sentença de pronúncia, o que remeteu a análise ao Tribunal de Justiça de São Paulo. Em julgamento ao recurso, o Tribunal manteve a decisão de pronúncia, por maioria. Interpostos embargos infringentes da decisão, foi novamente confirmada pelo Tribunal, através dos ricos debates a seguir comentados.

\footnotetext{
${ }^{53}$ Os adeptos dessa religião invocam tanto o Velho como o Novo Testamento para justificar a abstenção de receber sangue: Gênesis 9:4; Levítico 17:10; Deuteronômio 12:23; Atos 15:28, 29.
} 
O voto condutor do acórdão do Tribunal paulista, que entendeu pela necessidade de submissão do caso ao julgamento popular (Tribunal do Júri), defendeu que a vida deve se sobrepor e prevalecer sobre qualquer religião. Assim, uma vez em risco a vida do cidadão, as convicções religiosas devem ceder-lhe espaço. O entendimento é o mesmo que já preconizava MUÑOZ CONDE, para quem, quando o bem jurídico ameaçado pela delinquência por convicção classifica-se como bem jurídico individual (dentre eles, a vida), a decisão de consciência que lhe pretender violar não pode ter relevância, já que a liberdade de consciência teria menor importância do que a vida, como bem jurídico tutelado.

E foi assim que o desembargador Relator (Des. Roberto Midolla) fundamentou seu voto:

“(...) A vítima sofria de anemia falciforme e, na madrugada do dia 21 de julho de 1993, foi internada no Hospital São José, por apresentar um agravamento do seu estado de saúde em consequência dessa moléstia. Foi submetida a exames clínicos, onde se constatou a necessidade de uma transfusão de sangue. Esse diagnóstico foi apresentado aos pais da vítima que, apesar de todos os esclarecimentos feitos por médicos do hospital, se recusaram a permitir a transfusão de sangue na paciente, invocando preceitos religiosos da seita "Testemunhas de Jeová", do qual eram adeptos.

Com tal conduta, os pronunciados, para supostamente salvaguardar a salvação espiritual da vítima, impediram o procedimento médico adequado ao caso, concorreram para a sua morte e assumiram o risco pelo triste evento. 
Correta a decisão do v. Acórdão que os pronunciou, pois a recusa da transfusão de sangue por convicção religiosa, configurou, sim, em tese, o dolo eventual na morte de Juliana.

Destarte, respeitada a posição do douto Desembargador NUEVO CAMPOS, não há se falar em absolvição dos embargantes.

Em que pesem as referidas convicções religiosas dos acusados que, não obstante lhe são asseguradas constitucionalmente, a verdade é que a vida deve prevalecer acima de qualquer religião.

(...)

Caberá ao juízo natural da causa, o E. Tribunal do Júri, decidir qual dos dois lados está dizendo a verdade. Para tanto a pronúncia se impõe. A vítima tinha apenas 13 anos de idade e como absolutamente incapaz (artigo 5, inciso I, do Código Civil). Por força de lei, para todos os atos da vida civil, era representada pelos pais (artigo 384, inciso V do Código Civil). Assim, cabia aos pais e não a ela decidir acerca da submissão ao procedimento terapêutico.

(...)

Especialmente no caso do médicoembargante -JOSÉ AUGUSTO FALEIROS DINIZ causa estranheza a sua intervenção no sentido de não autorizar a transfusão de sangue na vítima, pois, ao se formar, o médico jura respeitar a vida humana, não permitindo que crenças religiosas interfiram no seu dever de salvar vidas.(...)" 
Já o voto vencido, da lavra de outro desembargador (Des. Souza Nery), não entendeu pela responsabilização dos religiosos, mas sim dos médicos que, mesmo sem a autorização dos pais, não agiram a evitar o resultado. Das suas colocações se extrai que, no caso de tipos penais que protegem direitos humanos fundamentais, a exculpação é condicionada à existência de uma alternativa neutra que dê efetiva proteção ao bem jurídico tutelado pela norma. Assim, com a negativa do genitor por motivos religiosos, o médico responsável deveria agir sozinho, ou ainda, por outra determinação (judicial ou não, a exemplo do conselho tutelar) que suprisse a recusa. $O$ que não poderia acontecer, de forma alguma, é o fato de consciência ser usado como motivo para a efetiva lesão de bens jurídicos individuais fundamentais.

$\mathrm{O}$ entendimento do voto vencido é o de que, independentemente de autorização dos pais, os médicos deveriam providenciar o tratamento adequado da criança na iminência do perigo de vida. Assim, o que resultou no óbito da criança não teria sido a falta de autorização para a transfusão, essa facilmente suprível, mas a inércia da equipe médica em desconsiderar essa negativa e realizar, de qualquer modo, a transfusão sanguínea na criança.

O aludido voto vencido seguiu assim fundamentado:

“(...) Dispõe a Constituição Federal, em seu artigo 5o,serem todos "iguais perante a lei, sem distinção de qualquer natureza, garantindo-se aos brasileiros e aos estrangeiros residentes no País, a inviolabilidade do direito à vida, à liberdade, à igualdade, à segurança e à propriedade", nos termos definidos pela Carta Política naquele mesmo dispositivo, dentre os quais, de interesse para o caso dos autos, desponta o inciso VI: é inviolável a liberdade de consciência e de crença, sendo 
assegurado o livre exercício dos cultos religiosos e garantida, na forma da lei, a proteção dos locais de culto e suas liturgias; Ora, se a liberdade de crença é efetivamente inviolável, não pode o cidadão, ao exercê-la, e só por exercê-la, sofrer nenhuma espécie de violação, ainda que promovida sob o manto aparente da lei.

Nem assim se lhes pode incriminar, diante da total inexistência de nexo de causalidade entre o obstáculo que pretendiam opor e a falta de tratamento adequado a ocasionar a morte da infanta.

É que a recusa dos pais da infeliz vítima era absolutamente irrelevante para o atendimento médico que lhe devia ter sido prestado.

O Código de Ética Médica (Resolução $\mathrm{n}^{\circ}$ CFM1.246/88, de 8 de janeiro), em seu artigo 46, proíbe o médico de " [e]fetuar qualquer procedimento médico sem o esclarecimento e consentimento prévios do paciente ou de seu representante legal, salvo iminente perigo de vida. O mesmo diploma legal, em outros dois dispositivos isenta de responsabilidade ética o profissional médico que, diante de pessoa entregue a greve de fome, intervenha para afastar o risco iminente da vida (artigo 51), e pune aquele que "desrespeitar o direito do paciente de decidir livremente sobre a execução de práticas diagnosticas ou terapêuticas, salvo em caso de iminente perigo de vida" (artigo 56).

O próprio Código Penal Brasileiro estabelece ser atípica a conduta do médico que realize intervenção, mesmo que cirúrgica, "sem o 
consentimento do paciente ou de seu representante legal, se justificada por iminente perigo devida (artigo 146, § 3o, inciso I).

Assim, admitir a responsabilidade penal dos embargantes corresponde a desobedecer o mandamento constitucional antes transcrito, por isso que seu ato limitou-se ao exercício de sua liberdade de crença, e no comportamento dela decorrente.

Ainda uma vez destaco ser a "proibição" da transfusão de sangue oposta pelos embargantes ao tratamento de sua filha absolutamente irrelevante sob o ponto de vista legal para os médicos encarregados de atendê-la, que tinham o dever de prestar-lhe toda a assistência necessária, agindo sob o manto protetor tanto de seu próprio Código de Ética, quanto, e mais importantemente, do Código Penal Brasileiro, como demonstrei. (...)"

O tema foi levado ao STJ, através de Recurso Especial e, em seguida, do HC no. 268.459/SP, impetrado em favor de um dos pronunciados, e submetido à Relatoria da Min. Maria Tereza Moura. Nesse sentido, a 6 ${ }^{\mathbf{a}}$ Turma concedeu a ordem de ofício, reconhecendo acerto no voto vencido do Tribunal a quo para trancar a ação penal com relação aos pais e entender que, se houve responsabilidade, seria dos médicos do hospital, que deveriam ter agido mesmo sem o consentimento dos pais:

PROCESSO PENAL. HABEAS CORPUS. HOMICÍDIO. (1) IMPETRAÇÃO COMO SUCEDÂNEO RECURSAL, APRESENTADA 
DEPOIS DA INTERPOSIÇÃO DE TODOS OS RECURSOS CABÍVEIS. IMPROPRIEDADE DA VIA ELEITA. (2) QUESTÕES DIVERSAS DAQUELAS JÁ ASSENTADAS EM ARESP E RHC POR ESTA CORTE. PATENTE ILEGALIDADE. RECONHECIMENTO. (3) LIBERDADE RELIGIOSA. ÂMBITO DE EXERCÍCIO. BIOÉTICA E BIODIREITO: PRINCÍPIO DA AUTONOMIA. RELEVÂNCIA DO CONSENTIMENTO ATINENTE À SITUAÇÃO DE RISCO DE VIDA DE ADOLESCENTE. DEVER MÉDICO DE INTERVENÇÃO. ATIPICIDADE DA CONDUTA. RECONHECIMENTO. ORDEM CONCEDIDA DE OFÍCIO.

1. (...)

3. Na espécie, como já assinalado nos votos vencidos, proferidos na origem, em sede de recurso em sentido estrito e embargos infringentes, tem-se como decisivo, para o desate da responsabilização criminal, a aferição do relevo do consentimento dos pacientes para o advento do resultado tido como delitivo. Em verdade, como inexistem direitos absolutos em nossa ordem constitucional, de igual forma a liberdade religiosa também se sujeita ao concerto axiológico, acomodando-se diante das demais condicionantes valorativas. Desta maneira, no caso em foco, ter-se-ia que aquilatar, a fim de bem se equacionar a 
expressão penal da conduta dos envolvidos, em que medida teria impacto a manifestação de vontade, religiosamente inspirada, dos pacientes. No juízo de ponderação, o peso dos bens jurídicos, de um lado, a vida e o superior interesse do adolescente, que ainda não teria discernimento suficiente (ao menos em termos legais) para deliberar sobre os rumos de seu tratamento médico, sobrepairam sobre, de outro lado, a convicção religiosa dos pais, que teriam se manifestado contrariamente à transfusão de sangue. Nesse panorama, tem-se como inócua a negativa de concordância para a providência terapêutica, agigantando-se, ademais, omissão do hospital, que, entendendo que seria imperiosa a intervenção, deveria, independentemente de qualquer posição dos pais, ter avançado pelo tratamento que entendiam ser o imprescindível para evitar a morte. Portanto, não há falar em tipicidade da conduta dos pais que, tendo levado sua filha para o hospital, mostrando que com ela se preocupavam, por convicção religiosa, não ofereceram consentimento para transfusão de sangue - pois, tal manifestação era indiferente para os médicos, que, nesse cenário, tinham o dever de salvar a vida. Contudo, os médicos do hospital, crendo que se tratava de medida indispensável para se evitar a morte, não poderiam privar a adolescente de qualquer 
procedimento, mas, antes, a eles cumpria avançar no cumprimento de seu dever profissional. 4. Ordem não conhecida, expedido habeas corpus de ofício para, reconhecida a atipicidade do comportamento irrogado, extinguir a ação penal em razão da atipicidade do comportamento irrogado aos pacientes ${ }^{54}$.

\section{Da provocação da situação de legítima defesa}

Quanto à provocação da situação de legítima defesa, tratase do caso do agente que, embora tenha provocado a agressão (o que faz o revide deixar de ser injusto, afastando a possibilidade de excluirse a antijuridicidade), não consiga desviar a ação de defesa do ofendido (fugindo, por exemplo). Nesses casos, admitir-se-ia a situação de exculpação, "porque o Estado não pode exigir de ninguém a renúncia ao direito de viver, nem criar situações sem saída, nas quais as alternativas são ou deixar-se matar ou sofrer uma pena rigorosa" ${ }^{55}$.

ZAFFARONI refere-se à situação de provocación de la necessidad, quando a provocação da situação de necessidade por parte do agente impede o afastamento do injusto (em razão de ter sido o próprio agente quem pôs em perigo o bem jurídico), lembrando que embora presente a antijuridicidade, nem sempre encontra-se presente

\footnotetext{
${ }^{54}$ STJ / HC no. 268.459/SP. Rel. Min Maria Tereza Moura. Julgado em 02.09.2014. Fonte: www.stj.jus.br. Acesso em 19 de abril de 2017.

${ }^{55}$ CIRINO DOS SANTOS, Juarez. Direito Penal: Parte Geral. $2^{a}$ ed. Curitiba: ICPC Editora Lúmen Iuris, 2007, p. 337.
} 
a culpabilidade, "pues no puede imponerse a nadie el deber jurídico de dejarse matar, mutilar o lesionar gravísimamente" ${ }^{\text {" }}$.

\section{Do Conflito de Deveres. Retomada da ideia de WELZEL, de eleição de um "mal menor". Equiparação com o estado de necessidade exculpante. A influência do direito alemão.}

Quanto ao conflito de deveres como quarta causa supralegal de inexigibilidade, CIRINO DOS SANTOS faz uso dos exemplos expostos por WELZEL para o estado de necessidade exculpante, referindo-se ao exemplo da eutanásia de doentes mentais durante o regime nazista ${ }^{57}$.

A hipótese de conflito de deveres, como já aduzido, quando na ponderação de bens é sacrificado o bem jurídico mais relevante, se enquadra no chamado estado de necessidade exculpante, previsto na legislação alemã como causa legal de exclusão da culpabilidade. O Código Penal brasileiro, por adotar a Teoria Unitária do Estado de Necessidade, não prevê tal possibilidade de exculpação (como já exposto no item 5.3 do capítulo 05 ), motivo pelo qual a colisão de deveres não enquadrada no estado de necessidade justificante pode ser vista como causa supralegal de não exigibilidade de conduta diversa, se, dadas as circunstâncias do fato, é inexigível que o agente suporte o sacrifício.

Pois bem. A doutrina aponta alguns exemplos tidos como controvertidos, nos quais apresenta a problemática do conflito de

\footnotetext{
56 ZAFFARONI, Eugenio Raúl. Estructura Basica del Derecho Penal. Buenos Aires: Ediar, 2009, p. 227.

${ }^{57}$ CIRINO DOS SANTOS, Juarez. Direito Penal: Parte Geral. 2a ed. Curitiba: ICPC Editora Lúmen Iuris, 2007, p. 390.
} 
deveres para o agente, por ocasião da conduta. Interessante observar esses exemplos, para entender a sistemática do conflito de deveres e, assim, delimitar as suas hipóteses e classificá-las - como se pretende nos casos de estado de necessidade exculpante, tal qual empreendia WELZEL.

Sobre o tema, explica CIRINO DOS SANTOS que, para evitar uma colisão com um trem de passageiros, determinando a morte de muitos, um funcionário da ferrovia desvia o trem de carga desgovernado para um trilho diferente, causando a morte certa de alguns trabalhadores. Haveria claro conflito de deveres, tendo o agente optado, da mesma forma que os médicos, pelo mal menor, sendo aquela ação o único meio de esse evitar um mal maior, e com o intuito de salvação (vide WELZEL).

Outro exemplo de conflito de deveres seria a escolha, pelo médico, dos pacientes que receberão a máquina de respiração/circulação artificial, considerando uma situação na qual sobram pacientes e falta o referido maquinário. Assim, a escolha do mal menor representaria a retirada da máquina do paciente com menor chance de sobrevivência para dar ao paciente com maior chance. $\mathrm{O}$ fundamento da exculpação seria o de que qualquer pessoa, no lugar do médico, poderia agir da mesma forma, e esse, no conflito do dever de salvar ambos os pacientes, mas tendo que eleger a proteção de um bem jurídico em detrimento de outro, agiu conforme sua consciência para perseguição do fim de salvação $0^{58}$.

Exemplo mais atual seria o abate de uma aeronave de passageiros sequestrada por terroristas, que estivesse prestes a ser usada

\footnotetext{
58 Nesse sentido, vide WELZEL, Hans. O Novo Sistema Jurídico Penal: uma introdução à doutrina da ação finalista. Tradução de Luiz Regis Prado. 2a Edição. São Paulo: RT, 2010, p. 156.
} 
como arma para ataques terroristas. Derrubar o referido avião, embora implicasse na morte de muitos passageiros inocentes, evitaria uma tragédia ainda maior, que seria o choque daquele avião com locais habitados.

Tem-se em comum, nos exemplos apresentados, que ao agente é dada uma escolha de comportamento antijurídico, sabedor que de, a depender de sua escolha, bens jurídicos de maior ou menor importância serão atingidos.

Para ARIEL DOTTI, se encaixa na situação de conflito de deveres os inúmeros precedentes brasileiros no sentido de reconhecer a inexigibilidade de conduta diversa no caso do empresário que omite o pagamento de contribuições previdenciárias em face das dificuldades financeiras de sua empresa ${ }^{59}$. É o caso, pois, no qual se contrapõem o dever de recolher a contribuição previdenciária e o dever de pagar os salários dos mesmos funcionários ou outras despesas inevitáveis ao funcionamento da empresa em graves dificuldades financeiras. Há, na hipótese, real conflito do autor em eleger um tipo de comportamento, que importe na escolha do mal menor.

Em razão de o Brasil adotar, no Código Penal comum, a Teoria Unitária do Estado de Necessidade, as hipóteses classificadas no $\S 35$ do Código Penal alemão (estado de necessidade desculpante) são aqui adotadas como causas supralegais de não exigibilidade. Dos próprios exemplos explicitados, vê-se que tais hipóteses, classificadas pela doutrina apontada sob o título de "conflito de deveres", estariam diretamente relacionadas à exculpante do estado de necessidade.

O estado de necessidade exculpante do direito penal alemão é aquele no qual, em situação de perigo para a vida, corpo, liberdade,

${ }^{59}$ DOTTI, René Ariel. Curso de Direito Penal: Parte geral. São Paulo: RT, 2010, p. 515. 
honra, propriedade ou outro bem jurídico, sendo essa situação não evitável, se comete um fato antijurídico para evitar um perigo para si, um parente ou outrem (§35). Nesse caso, a alusão da lei ao "fato antijurídico" já pressupõe que, na ponderação dos bens jurídicos em conflito, foram sacrificados bens de maior importância do que os resguardados com a conduta.

Assim, o estado de necessidade exculpante ocorre quando o agente sacrifica bem de maior valor para salvar outro de menor valor, mas naquela ocasião não lhe é possível exigir outro comportamento. A sua diferença ao estado de necessidade justificante se baseia, portanto, na ponderação de bens, já que, para caracterizar-se esse último e o direito aprovar a conduta do agente, afastando a ilicitude, deve o bem sacrificado ser de valor menor do que o salvo com o comportamento.

Explica BITENCOURT que, no Brasil, pela adoção da Teoria Unitária, quando há desproporcionalidade entre os bens em conflito e perece o mais valioso, afasta-se legalmente não só o estado de necessidade justificante, mas o exculpante ${ }^{60}$. Nada impediria, ressalta o autor brasileiro, que se caracterizasse a inexigibilidade de conduta diversa, através do exemplo típico da colisão de deveres, "onde o agente deve optar por uma alternativa, isto é, pelo cumprimento de um dever em detrimento de outro, e a sua escolha não recair exatamente naquela mais adequada aos fins do direito"61. Nesse raciocínio, "a colisão de deveres configura uma espécie de estado de necessidade, na medida em que todo dever está vinculado a um determinado bem jurídico" ${ }^{2}$.

\footnotetext{
${ }^{60}$ BITENCOURT, Cezar Roberto. Manual de Direito Penal. Parte geral. Vol. 01. São Paulo: Saraiva, 2000, p. 252.

${ }^{61}$ Idem, ibidem, p. 253.

${ }^{62}$ Idem, ibidem, p. 253.
} 
Imagine-se o quadro de um naufrágio, com mar revolto, no qual quatro crianças estão à deriva, afogando-se, três delas juntas, e uma mais afastada, que não poderá alcançar o grupo em tempo de não se afogar. Com a aproximação do bote para ajudá-las, o marinheiro prefere jogar a única boia salva-vidas para o lado do garoto isolado, salvando apenas uma criança, ao tempo em que as outras se afogavam, enquanto poderia ter salvo três vidas, içando, através da boia, as três crianças que estavam mais próximas. No caso do conflito de deveres, escolheu-se indevidamente o sacrifício do mal maior - três vidas - para salvar-se apenas uma vida, o que já afastaria a hipótese de estado de necessidade justificante. No entanto, imagine-se que o garoto salvo era filho do marinheiro, fato que o motivou a salvá-lo em detrimento das outras crianças. Diante desse fato, sua conduta não pode ser reprovável pelo direito, ante a impossibilidade de exigir-lhe o sacrifício de ver seu filho afogar-se, para salvar crianças desconhecidas. Esse exemplo, no direito alemão, se enquadraria no estado de necessidade desculpante do §35. No direito brasileiro, é causa supralegal de não exigibilidade. Estaria inserida, na classificação da doutrina, como causa supralegal de inexigibilidade prevista como "conflito de deveres".

Qualquer escolha do autor, nesse caso, atingiria um bem jurídico. Qualquer escolha do autor, por sua vez, sacrificaria um dever, violando o outro bem jurídico. A escolha final, por tratar-se de sacrifício do bem maior, excluiria a hipótese de estado de necessidade justificante, mas ao mesmo tempo o direito não poderia exigir do agente o sacrifício do bem eleito para ser salvo.

Observe a já mencionada hipótese de não exigibilidade ante o não recolhimento de contribuições previdenciárias. $O$ agente poderia pagar o salário dos funcionários e manter a empresa funcionando, mas para isso teria que deixar de recolher as contribuições previdenciárias, já que não dispunha de capital a honrar 
ambas as obrigações financeiras. Qualquer escolha que fizesse representaria o descumprimento de um dever legal para honrar outro.

A última década mostrou uma grande incidência de julgados dos Tribunais Regionais Federais do país que reconhecem a inexigibilidade de conduta diversa supralegal na apuração da conduta do artigo 168-A do Código Penal brasileiro (não recolhimento de contribuições previdenciárias), dando conta do conflito de dever, do empresário, entre o pagamento da contribuição previdenciária e o pagamento de outras despesas cujo inadimplemento importassem no encerramento das atividades da empresa.

Embora os julgados não definam a causa supralegal de inexigibilidade com a denominação criada pela doutrina ("conflito de deveres"), é de amplo conhecimento a tendência jurisprudencial brasileira em acatar a tese de não exigibilidade de conduta diversa supralegal no caso de restarem cabalmente comprovadas as dificuldades financeiras da empresa como motivação ao ato de não recolhimento das contribuições dos funcionários, afastando a incidência, por parte do empresário, no tipo penal do art. 168-A do Código Penal.

Nesse sentido, apenas a título exemplificativo, citam-se abaixo as referências de alguns julgados dos cinco Tribunais Regionais Federais, competentes à análise desse crime federal, trazendo, a seguir, apenas uma ementa dentre as diversas sobre o assunto:

PENAL E PROCESSUAL PENAL. DELITO DE APROPRIAÇÃO INDÉBITA PREVIDENCIÁRIA. ALEGATIVA DE INEXIGIBILIDADE DE CONDUTA DIVERSA. GRAVES DIFICULDADES FINANCEIRAS ATRAVESSADAS PELA EMPRESA GERIDA PELO ACUSADO. COMPROVAÇÃO DE QUE HAVIA 38 EXECUÇÕES FISCAIS AJUIZADAS CONTRA A 
MESMA. DOLO ESPECIFICO DO AGENTE DE FRAUDAR A PREVIDENNCIA SOCIAL QUE SE AFASTA. APELO CRIMINAL DESPROVIDO.

1. Apelação Criminal, interposta contra sentença que julgou improcedente a denúncia, absolvendo o réu por insuficiência de provas, da imputação da prática do delito de apropriação indébita previdenciária, descrito no art. 168-A do Código Penal. O magistrado sentenciante asseverou que a afirmação do Réu sobre o quadro financeiro precário da empresa não fora infirmada, de modo que não ficou provado, com o que se colheu na via judicial, o dolo na conduta do desconto e não recolhimento das contribuições previdenciárias.

2. Narra a denúncia que (...) em fiscalização levada a efeito nos documentos de (...)., com sede em João Pessoa$\mathrm{PB}$, a Previdência Social constatou que referida empresa, no período de outubro de 1995 a abril de 1996, contanto tenha feito o desconto nos salários de seus empregado, pertinente às contribuições previdenciárias, deixou de efetuar o devido recolhimento aos cofres da autarquia, conforme está demonstrado nos relatórios fiscais que acompanham a presente. (...) O débito, até a data da denúncia, não foi quitado nem parcelado. $O$ denunciado, sócio proprietário de $50 \%$ (cinquenta por cento) da firma, tendo como sócia a Sra. (...), sempre foi seu gerente e administrador e assumiu o não recolhimento das contribuições previdenciárias "por mal ter dinheiro para pagar os salários". Assim, o MPF denunciou o Réu como incurso nas penas do art. 95, parágrafo 1으, da Lei $\mathrm{n}^{\circ}$ 8.212/91, pela prática do tipo descrito na alínea "d" desse mesmo artigo, combinado com o art. 71 do Código Penal. (...)

3. No que respeita à argüida inexigibilidade de conduta diversa, a mesma apenas se configura se ao agente não se apresenta outra opção de agir, fato a ser provado no curso da instrução pela Defesa, nos termos do artigo 156 do 
Código de Processo Penal, já que se trata de excludente de culpabilidade argüida pelo réu. De fato, a mera alegação de dificuldades financeiras, desacompanhada de prova pericial contábil ou de outros meios aptos a demonstrá-la, não é suficiente para a caracterização da referida excludente. (TRF 2a R. - Proc. 1996.50.01.007618-0/ES - (4282) - 1a T.Esp. - Rel. Des. Fed. Sergio Feltrin Corêa - DJU 01.12.2006 - p. 222).

4. Não obstante, no caso dos autos, não há como se divergir do entendimento sufragado pelo Juízo a quo, haja vista a demonstração, por meio de prova cabal, das contingências de ordem econômica que impediram o apelado de recolher as contribuições previdenciárias descontadas dos empregados, de modo a configurar a inexigibilidade de conduta diversa, como causa excludente de culpabilidade.

5. Para comprovar a gravidade da crise experimentada pela empresa, trouxe o Acusado aos autos movimentação processual colhida no sítio da Justiça Federal da Paraíba, elencando 38 (trinta e oito) Execuções Fiscais ajuizadas contra sua empresa, o que corrobora plenamente sua alegativa de que a empresa atravessava graves dificuldades financeiras, afastando-se o dolo específico do agente de fraudar a Previdência Social.

6.(...).

7. Precedentes desta Corte: RVCR 2008.05.00.055639-8

- PLENO - Rel. Des. Rogério Fialho Moreira - DJe 28.05.2010; ACR 6969/PE - 4a T. - Rel. Des. José Baptista - DJe 16.07.2010.

8. Impõe-se reconhecer em favor do Recorrido a causa supralegal de exclusão de culpabilidade, por inexigibilidade de conduta diversa.

9. Apelo Criminal conhecido, mas desprovido.

(Origem: Tribunal Regional Federal - 5a Região. Classe: Apelação Criminal - ACR6793/PB / Número do Processo: 200905000503374Órgão Julgador: Segunda Turma. Data 
do Julgamento: 19/10/2010Código do Documento: 243485Relator: Desembargador Federal Francisco Barros Dias Revisor: Desembargador Federal Paulo Gadelha Diário da Justiça Eletrônico TRF5 (DJE) - 27/10/2010 Página 236, UNÂNIME) (grifado)

Vide, no mesmo sentido, entre inúmeros julgados semelhantes: TRF DA 1o REGIÃO: (I) ACR - 200433000057083, Quarta Turma, e-djf1 data: 29/09/2009 pagina:512; (II) ACR 200138000341643, Quarta Turma, e-djf1 data:02/06/2009 pagina:234; (III) ACR - 199841000005012, Quarta Turma, DJ data:19/01/2006 pág:18; TRF DA 2a REGIÃO: (I) ACR 6812, Primeira Turma Especializada, E-DJF2R - Data:03/03/2011 - p.:211/212; (II) ACR 7893, Primeira Turma Especializada, E-DJF2R - Data:21/09/2010 pág:103; (III) ACR -7189, Segunda Turma Especializada, E-DJF2R Data::10/08/2010 - pág:236/237; TRF DA 3a REGIÃO: (I) ACR - 35229, Segunda Turma, DJF3 CJ1 data:18/11/2010 pág: 399; (II) ACR-39416, Primeira Turma, DJF3 CJ1 data:08/10/2010 p.: 202; (III) ACR - 36803, Primeira Turma, DJF3 CJ1 data: 24/06/2010 p.: 15; TRF DA 4a. REGIÃO: (I) ACR 200871160001368, Oitava Turma, D.E. 06/05/2009, (II) ACR 200571160037258, Sétima Turma, D.E. 24/09/2008; (III) ACR 200571080036146, Sétima Turma, D.E. 28/11/2007; TRF DA 5a REGIÃO: (I) ACR - 6683, Segunda Turma, DJE - Data:27/01/2011 P.:364; (II) ACR 6948, Segunda Turma, DJE - Data:17/02/2011 Pág:305; (III) ACR 5951, Primeira Turma, DJE - Data:25/11/2010 Pág:352.

6. Outra classificação. A criação da exigibilidade em três níveis como formas de identificação de causas supralegais. 
Partindo do pressuposto de que o legislador não poderia prever todos os possíveis casos de não exigibilidade, e que para se impor uma pena era necessário verificar que a conduta imposta pela norma era exigível ao agente também por razões lógicas derivadas da validez racional da norma primária (e não meramente por razões de imposição coercitiva do Estado), a doutrina espanhola de DE LA CUESTA AGUADO criou três níveis para que o julgador, em dúvida plantada pelo destinatário da norma, pudesse verificar se a conduta conforme a norma era exigível ou não ao agente ${ }^{63}$.

Tais níveis, embora apresentados com roupagem diferente dos modelos de comportamento já estudados, também são vistos como meios de identificação de causas supralegais, e alguns deles se assemelham às causas já nominadas.

$\mathrm{Na}$ realidade, tal modelo proposto pela doutrina espanhola, com classificações em três níveis, delimita os casos de não exigibilidade supralegal a partir da conferência de conteúdo normativo ao conceito jurídico de integridade moral e ao princípio da dignidade da pessoa humana (primeiro e segundo níveis) e empreende uma interpretação ao princípio da igualdade perante a lei (terceiro nível de exigibilidade).

O primeiro nível do juízo de exigibilidade encontra sua base nas situações nas quais o destinatário não reconhece a racionalidade da norma para gerar a ele um dever de conduta. É o denominado "dissenso normativo", que pode ser, segundo a professora da Universidade de Cádiz, ideológico ou prático ${ }^{64}$.

No dissenso prático, o destinatário da norma reconhece o valor defendido pela lei, mas se vê forçado a descumpri-la. No dissenso

${ }^{63}$ DE LA CUESTA AGUADO, Paz M. Culpabilidad: Exigibilidad y Razones para la Exculpación. Madrid: UCA, 2003, p. 229-230.

${ }^{64}$ DE LA CUESTA AGUADO, Paz M. Culpabilidad: Exigibilidad y Razones para la Exculpación. Madrid: UCA, 2003, p. 232. 
ideológico, o agente não admite a norma como válida por reputá-la irracional, no sentido de ser a mesma destoante do valor que o agente considera preeminente ${ }^{65}$. Em um direito penal democrático, explica a autora, deve-se levar em conta o número de pessoas tidas por "dissidentes", para ensejar a inclusão expressa de novas causas de exclusão da culpabilidade ou, ainda, a adoção de um conceito de culpabilidade material que parta de um conceito de destinatário da norma (modelo ideal de pessoa), adequado a um sistema democrático, plural e complexo ${ }^{66}$.

A ideia central desse primeiro nível é entendida como o respeito à diversidade humana, ideia que se pode reputar semelhante à que MUÑOZ CONDE trabalhou como "fato de consciência". DE LA CUESTA AGUADO vai um pouco mais além, definindo para essa ideia central a classificação em duas formas (dissenso ideológico e prático).

É claro que o julgador enfrentará dificuldades em identificar quem admite a racionalidade da norma mas não lhe interessa cumpri-la (ou se vê impelido a descumpri-la) e quem não admite essa racionalidade, motivando nessa inadmissão $o$ descumprimento da norma. No entanto, a mesma dificuldade já teria o Magistrado em identificar se em casos específicos se aplicaria ou não a inexigibilidade supralegal, sendo justamente a dificuldade de constatação das causas supralegais o que motiva a determinação dos modelos ora abordados.

O segundo nível do juízo de exigibilidade estaria baseado no conceito de dignidade da pessoa humana, princípio através do qual todas as pessoas deveriam receber o mesmo tratamento, e a toda pessoa deve ser endereçado um conjunto de direitos e deveres

\footnotetext{
${ }^{65}$ Idem, ibidem, p. 232.

${ }^{66}$ Idem, ibidem, p. 233.
} 
internacionalmente reconhecidos, expressando a obrigação que têm os poderes públicos e os indivíduos de respeitar esse conjunto de direitos e deveres ${ }^{67}$. Como decorrência desse princípio, o ius puninendi não pode exigir condutas que signifiquem um desprezo dos direitos e faculdades da pessoa humana, e esse critério permitiria a exculpação de condutas que fossem reflexos da anterior infringência do Princípio da Dignidade da Pessoa Humana.

Nesse segundo nível, DE LA CUESTA AGUADO afirma que seria possível exculpar a mulher que decide praticar o aborto, quando essa mesma mulher havia sido objeto de técnicas de reprodução assistida sem seu consentimento (nesse caso, o aborto não estaria autorizado por nenhuma das hipóteses que tratam do aborto não punível, e nem a mãe nem a criança padeceriam de enfermidades). A conduta, embora típica e antijurídica, não poderia ser culpável já que obrigar a gestante a seguir adiante com a gravidez significaria nada menos do que a lesão aos direitos fundamentais da pessoa ${ }^{68}$.

Ousa-se afirmar que dentro dessa hipótese estaria o clássico caso da siciliana de dezenove anos que, tendo sido abusada durante anos por seu tio, com a conivência da tia, e após perder o esposo quando o fato veio a público, praticou homicídio contra ambos os tios. O júri popular a absolveu entendendo pela impossibilidade de reprovála já que, em sua rudimentar instrução, não opôs resistência à concepção imperante na sua cidade natal, executando a morte daqueles que haviam lhe roubado a honra e a alegria do casamento ${ }^{69}$.

${ }^{67}$ DE LA CUESTA AGUADO, Paz M. Culpabilidad: Exigibilidad y Razones para la Exculpación.Madrid: UCA, 2003, p. 237-238.

${ }^{68}$ Idem, ibidem, p. 238.

${ }^{69}$ Trata-se do caso da siciliana que teria vindo da Sicília para Nova York aos sete anos, para residir com um casal de tios. Durante anos, a menina foi abusada sexualmente pelo tio, com o conhecimento da tia. Um jovem italiano a desposou, e ambos estavam 
Verificando o Magistrado que a norma penal regulava conduta dentro do âmbito de competência do ius puniendi e seu cumprimento não significava desrespeito por parte do destinatário da norma (primeiro nível) ou sacrifício intolerável ante o desrespeito à dignidade da pessoa (segundo nível), a norma ainda poderia ser tida por inexigível quando, dadas as circunstâncias, a comparação entre o modelo de pessoa e o caso concreto se diferenciassem de outros casos, de forma que, embora a norma pudesse ser exigida a outras pessoas, exigir-se o cumprimento da norma por aquele agente, naquelas circunstâncias, infringiria o princípio de igualdade diante da lei ${ }^{70}$. É o caso do terceiro nível do juízo de exigibilidade.

Sobre esse terceiro nível, DE LA CUESTA AGUADO esclarece que, da mesma forma que se deve admitir distinto tratamento jurídico entre pessoas normais ante o reconhecimento de que não é idêntica a situação de quem sabe da obrigação advinda da norma e de quem a desconhece ou crê que naquele caso concreto inexistia o dever de atuação (teoria do erro), a análise da exigibilidade também deve ser tida através da valoração do caso concreto individual.

É que, posto que a culpabilidade é o elemento do delito no qual se valora o caso concreto e o agente individualmente considerado, bem como a medida da adequação de seu comportamento ao mandato normativo, o aprofundamento na diferenciação das circunstâncias relevantes ao caso especificamente considerado, ainda que sejam circunstâncias minimamente relevantes, significará o aprofundamento do princípio da igualdade ante a lei e do sistema democrático baseado

felizes até que a tia revelou ao esposo que a moça mantivera relações sexuais com o tio. Após ser abandonada pelo consorte, a jovem resolveu vingar-se dos tios, seguindo a concepção popular siciliana, matando-os para restaurar sua honra perdida.

${ }^{70}$ DE LA CUESTA AgUADO, Paz M. Op. Cit., p. 239. 
no respeito ao indivíduo ${ }^{71}$. Assim, se na sociedade nem todas as posições sociais são idênticas, ao lado das razões biológicas, existiriam também razões de caráter social que fazem com que todos os destinatários da norma jurídico-penal não se encontrem em idêntica situação frente à norma ${ }^{72}$.

Ao definir o terceiro nível, no nosso entender, a autora espanhola tratou menos de uma forma de identificação de causa supralegal e mais de um critério para determinação da aplicação da não exigibilidade (vide, no capítulo primeiro, os critérios para determinação do poder atuar de outro modo). Nesse sentido, voltandose aos casos de aplicação desse terceiro nível, qualquer análise subjetiva do autor da conduta que o diferenciasse ou diferenciasse a situação fática por ele vivida do modelo normal exigível (homem médio e circunstâncias normais) e trouxesse, por isso, nova valoração do caso concreto individual para afastar a culpabilidade, poderia estar incluída nesse terceiro nível.

\section{Casos reconhecidos pelo judiciário brasileiro que não se enquadram na classificação doutrinária apresentada. A possibilidade de surgimento de outras classificações.}

ASSIS TOLEDO já trouxera, em sua obra datada de 1994, a previsão do reconhecimento da inexigibilidade de outra conduta como causa supralegal de exclusão da culpabilidade pelo Superior Tribunal de Justiça através do recurso especial no. 2492/RS datado de 1990, o qual reconhecia a possibilidade de sustentar-se a tese em julgamento

\footnotetext{
${ }^{71}$ DE LA CUESTA AGUADO, Paz M. Culpabilidad: Exigibilidad y Razones para la Exculpación.Madrid: UCA, 2003, p. 240.

72 Idem, ibidem, p. 241.
} 
pelo júri, devendo os quesitos sobre o assunto serem endereçados aos jurados $^{73}$.

No mesmo ano de 1994, em revista do Ministério Público de Minas Gerais, a doutrina de WANDERLEY ANDRADE atentava para a relutância da magistratura brasileira em adotar a tese da não exigibilidade supralegal, com receio de que "se introduza na muralha do direito positivo uma brecha inconveniente, por onde venham a escapar da merecida punição os acusados que não se enquadrem, rigorosamente, nas excepcionalidades a que se refere a teoria da inexigibilidade" 74 . No entanto, o referido artigo trouxe à análise, além do julgado já mencionado, da lavra do egrégio STJ, a jurisprudência dos extintos Tribunais de Alçada Criminal do Estado de São Paulo (TACRIM/SP), consubstanciada em 04 decisões anteriores à do STJ, oriundas do referido Tribunal paulista e datadas dos anos de 1988, 1989 e $1990^{75}$.

A primeira decisão do Tribunal de Alçada Criminal de São Paulo versava acerca da conduta de um motorista que acionara o seu veículo contra uma multidão de "bêbados e drogados", que comemoravam uma vitória esportiva e praticavam atos de vandalismo contra o veículo. $\mathrm{O}$ Tribunal entendeu que não poderia condenar o motorista, mormente porque se encontravam no veículo a sua esposa

\footnotetext{
${ }^{73}$ STJ - RESP 2492-RS, Rel. Min. ASSIS TOLEDO, Dj. 06.08.1990.

74 WANDERLEY ANDRADE. A inexigibilidade de outra conduta como causa excludente de culpabilidade. Revista JUS, Revista Jurídica do Ministério Público do Estado de Minas Gerais. Belo Horizonte: Vol. 17, ano 1994, p. 381-407.

${ }^{75}$ Ibidem, p. 388-390. Deixou-se de citar outras três decisões trazidas no referido artigo, que, embora tragam a expressão "inexigibilidade de outra conduta", referemse, na verdade, ao afastamento da tipicidade e da ilicitude.
} 
e filhos menores, pretendendo o mesmo, ao praticar a lesão corporal culposa, sair daquele local conturbado (apelação no. 488.605/7) ${ }^{76}$.

A inexigibilidade supralegal, no caso analisado, poderia ser classificada como estado de necessidade exculpante, tendo-se uma situação de perigo atual provocada pela multidão, se entendermos que os atos representativos da manifestação da multidão não sejam ilícitos ${ }^{77}$. O caso, assim, poderia caracterizar "conflito de deveres", pois, embora o agente tenha eleito o sacrifício de bem de maior valor (praticando lesão corporal na direção de veículo) para proteger-se de danos ao seu veículo e possibilidade de risco à saúde de sua família, era inexigível pelo direito que assim não agisse. Em não se admitindo que os atos da multidão pudessem ensejar o quadro de estado de necessidade, a hipótese torna-se sem enquadramento nos modelos estudados.

Em continuidade, têm-se os julgados da apelação no. $546.343 / 9$, que absolveu a mulher que agrediu o marido diante da humilhação que este a fez passar $^{78}$, e do acórdão 535181-9, do mesmo

${ }^{76}$ Apelação n. 488.605/7, 9a Câmara Criminal do Tribunal de Alçada Criminal de São Paulo, oriundo da comarca de Jaú/SP, julgado em 02.03.1998. Revista Julgados do TACrim - SP v. 4, p. 110.

77 Para BITENCOURT, é indiferente que a situação de perigo tenha sido causada por conduta humana ou decorra de fato natural (Manual de Direito Penal. Parte geral. Vol. 01. São Paulo: Saraiva, 2000, p. 255). Já BRANDÃO, registra que o perigo atual pode ser originado de várias formas, como força da natureza, de ataques de animais, de ação humana lícita e movimentos humanos reflexos nos quais não exista intervenção da vontade. (Teoria Jurídica do Crime. Rio de Janeiro: Forense, 2003,p. 111). Não se admite, pois, que a ação humana ilícita possa ensejar o perigo atual de que fala o art. 24 do CP.

${ }^{78}$ Acórdão do TACRIM/SP - Revista Julgados do TACrim, v. 4, p.113, julgado pela 5aㅡ Câmara Criminal em 09.08.1989, Cf. WANDERLEY ANDRADE, Op. Cit., p. 388390. 
TACRIM/SP, que, no ano de 1989, já previa a tese de inexigibilidade de conduta diversa por dificuldades financeiras, absolvendo-se de crime contra a economia popular um agente que praticou o fato em época de "imposições e pressões criadas por uma terrível crise econômica, geradora de certas distorções e anormalidades incontornáveis"79.

Antes de comentar ambos os julgados, contudo, urge tomar-se para análise o recurso extraordinário oo. 460.880-4/RS, datado do ano de 2007, julgado no Supremo Tribunal Federal, o qual tratava da prática do crime de resistência contra a tentativa de um oficial de justiça que, no exercício de seu mister, pretendia intimar a esposa enferma do acusado em um sábado à noite, adentrando na residência do mesmo. O referido oficial dispunha de mandado judicial que autorizava, expressamente, o cumprimento da referida ordem até mesmo em dia de domingo, e em horário diverso daquele estabelecido na legislação. Julgando o feito, o STF entendeu que o caso deveria ser apreciado tendo como plano secundário a defesa do próprio domicílio. Assim, teve como caracterizada a ofensa ao preceito da Constituição Federal que tutela a inviolabilidade noturna do domicílio, pouco importando, nesse caso, a existência de ordem judicial que assim o autorizasse. Tendo por violado o inciso XI do art. 5o da CF/88, o qual reza que a casa é o asilo inviolável do indivíduo, ninguém podendo nela penetrar senão com o consentimento do morador - salvo em flagrante delito, desastre ou para prestar socorro, ou, ainda, durante o dia, com mandado judicial -, entenderam os Ministros do STF que não se podia exigir do agente outra conduta que não a de resistência à

\footnotetext{
${ }^{79}$ Revista dos julgados do TACrim, v. 3, p.106, em 20.04.1989, Cf. WANDERLEY ANDRADE. A inexigibilidade de outra conduta como causa excludente de culpabilidade. Revista JUS, Revista Jurídica do Ministério Público do Estado de Minas Gerais. Belo Horizonte: Vol. 17, ano 1994, p. 388.
} 
tentativa de intimação de sua esposa. Tal comportamento desconforme à norma nada mais seria do que a defesa do seu direito ao asilo inviolável abalizado pela Constituição Federal ${ }^{80}$.

Tendo-se por base essa decisão, já se percebe a dificuldade de enquadrá-la nas quatro fórmulas apresentadas na doutrina brasileira. Ora, refutando-se de antemão a provocação de legítima defesa e o fato de consciência, por totalmente inaplicáveis, impende constatar da impossibilidade de enquadramento do caso no modelo de desobediência civil (embora o crime de resistência possa se caracterizar como uma desobediência, com o acréscimo de violência ou ameaça), já que se exige, para esse último, a defesa de interesses de uma coletividade. Ainda, tampouco se pode dizer que o caso em epígrafe relacionar-se-ia à classificação de conflito de deveres, já que não são apresentadas ao agente as duas situações que representem a colisão de obrigações, e o fato de um oficial de justiça pretender adentrar na residência de um cidadão, ainda que em horário e dia inoportunos, não autorizaria a caracterização de estado de necessidade, a legitimar a ponderação de bens inerente ao estado de necessidade exculpante. Ante o exposto, pode-se constatar que o referido julgado não se coaduna com as quatro hipóteses catalogadas pela doutrina brasileira.

${ }^{80}$ É possível defender que a conduta do agente, nesse caso, estaria acobertada pela legítima defesa do seu domicílio como causa excludente de antijuridicidade. É digno de nota, no entanto, que como o Supremo Tribunal Federal classificou a hipótese como inexigibilidade de conduta diversa, preferindo afastar a culpabilidade, e, ainda, dada a dificuldade de se reputar como "injusta agressão" a ação do oficial de justiça acobertada por mandado judicial (que se caracteriza, naquele momento, como "ordem legal", ainda que posteriormente verificada sua inconstitucionalidade), preferiu-se desposar do entendimento do STF, dando continuidade ao raciocínio de enquadramento da hipótese nos modelos de causas supralegais de exclusão da culpabilidade por inexigibilidade de conduta diversa. 
Vê-se, no entanto, que a ponderação de direitos analisada pelo Supremo Tribunal Federal - entre o exercício profissional do oficial de justiça e exercício do direito de ter sua residência imaculada senão nas hipóteses constitucionalmente previstas - demonstra que o exercício da atividade do oficial de justiça, da forma na qual se restou apresentado, afrontava importante garantia constitucionalmente assegurada, relacionada a um dos mais comezinhos direitos do cidadão, o do resguardo de seu domicílio, diretamente vinculado à obrigação do poder público em respeitá-lo. Assim, embora ausente o enquadramento nos quatro modelos brasileiros de redução das causas de supralegalidade, insta observar que o resultado do julgamento se encaixaria no raciocínio formulado no segundo nível do reconhecimento da inexigibilidade supralegal formulado por DE LA CUESTA AGUADO, para o qual o ius puniendi não poderia exigir condutas que significassem o desprezo dos direitos da pessoa humana.

Em conclusão, a lacuna deixada pelas hipóteses já formuladas seria preenchida pela solução dada pela autora espanhola, em outra classificação absolutamente independente.

A mesma solução entende-se conveniente ao caso já referido acima, do julgado do TACRIM/SP, o qual absolveu a mulher que agrediu o marido diante da humilhação que o mesmo a fez passar (apelação 546.343/9, trazida pela doutrina de WANDERLEY ANDRADE). Vendo-se atingida em sua honra e considerando o aviltamento de seu decoro (o que atinge sua dignidade como pessoa), a mulher foi instada ao revide, sem que a hipótese pudesse se classificar como legítima defesa, dada a não atualidade da agressão injusta. Também não haveria conflito de bens, não se falando em estado de necessidade exculpante, nem fato de consciência, provocação de legítima defesa ou desobediência civil. A classificação do segundo nível de DE LA CUESTA AGUADO daria a solução ao caso, que se 
assemelha, aliás, ao comentado julgado da siciliana que, seguindo os costumes de sua comunidade, resolveu pôr termo à vida de seus tios que a tinham submetido a graves constrangimentos.

Outra situação também deve ser trazida à baila para discussão ainda quanto à falibilidade dos modelos apresentados pela doutrina brasileira. É o caso de crimes patrimoniais praticados por pessoas submetidas à situação de miserabilidade ou outro infortúnio, e que não encontraram no Estado o apoio necessário ao sustento próprio ou de sua família (emprego, educação básica e atendimento médico).

Ao tratar de conflito de deveres, CIRINO DOS SANTOS, no que é apoiado pela doutrina de ARIEL DOTTI, registra que "situações de conflito de deveres ainda mais relevantes são comuns no contexto de condições sociais adversas", referentes a crimes patrimoniais relacionados à preservação de valores e da sobrevivência própria e familiar: "quando condições de existência social adversas deixam de ser a exceção transitória para ser a regra constante da vida das massas miserabilizadas, então o crime pode constituir resposta normal de sujeitos em situação social anormap's1. Tratar-se-iam de crimes patrimoniais cometidos por pessoas marginalizadas que tiveram frustradas as suas tentativas de obter espaço no mercado de trabalho, e assim agiam para impedir a desintegração de suas famílias, a prostituição de suas filhas, a inserção de seus filhos no mundo do crime, etc.

Aduz o autor que, nessas condições, "os critérios normais de valoração do comportamento individual devem mudar”, para utilizar-

${ }^{81}$ CIRINO DOS SANTOS, Juarez. Direito Penal: Parte Geral. 2a ed. Curitiba: ICPC Editora Lúmen Iuris, 2007, p. 341-342. 
se de "pautas excepcionais de inexigibilidade" a fundamentar hipóteses supralegais de exculpação por conflito de deveres ${ }^{82}$.

A doutrina de DOTTI comunga da mesma opinião, afirmando tratar-se da tese da coculpabilidade do Estado, que, ao deixar de cumprir os deveres essenciais de assistência aos necessitados, acabou por renunciar ao dever de punição ${ }^{83}$.

É certo que a jurisprudência já afastou a culpabilidade do agente quando se trata de crime famélico. Não se admite, no entanto, o êxito da referida tese defensiva quando se alega meras dificuldades financeiras ou desemprego, entendendo os Tribunais Superiores que deve restar comprovada, para tal, a situação extremada de penúria ${ }^{84}$. Tem-se que, no direito brasileiro, a tese da coculpabilidade do Estado não encontra guarida na jurisprudência, na medida em que as

${ }^{82}$ Idem, ibidem, p.342.

${ }^{83}$ DOTTI, René Ariel. Curso de Direito Penal: Parte geral. São Paulo: RT, 2010, p. 515.

${ }^{84}$ A título meramente exemplificativo: PENAL - PROCESSUAL PENAL - (...) COMETIMENTO DO DELITO EM RAZÃO DE DIFICULDADES FINANCEIRAS SUPORTADAS PELO RÉU NÃO COMPROVADAS (...). 4. (...) Não se tratou, pois, de crime famélico ou de situação extremada de penúria, a permitir a exclusão da ilicitude ou da culpabilidade por inexigibilidade de conduta diversa, como invocado pela defesa. 6. Todavia, não se pode admitir que meras dificuldades financeiras ou mesmo o desemprego pelo qual, infelizmente, atravessam milhares de famílias brasileiras, justifiquem o cometimento de crimes e o descaso ao ordenamento jurídico. 7. Desnecessário tecer mais argumentos sobre os aspectos particulares da vida do réu acerca das alternativas viáveis de que poderia ter lançado mão, para fugir do alegado "estado de penúria e desespero" em que a defesa alega que se encontrava. Afastada a causa de exclusão de ilicitude arguida pelo réu. 8. (...) 24. Recurso da defesa parcialmente provido. Sentença mantida quanto ao mais. (TRF da 3a Quinta Turma - DJF3 CJ1 DATA:16/05/2011 pag. 780 ACR 200161190028718 30582 . Rel. JUIZA RAMZA TARTUCE. Data da decisão: 09/05/2011) 
alegações de desemprego e dificuldades financeiras não são aceitas como justificativas ao cometimento desses tipos de crimes.

Sem discutir o mérito e a razoabilidade dos argumentos invocados por CIRINO DOS SANTOS, entende-se, no entanto, que a hipótese não se enquadra na situação de "conflito de deveres", tampouco em alguma das outras três situações delineadas (fato de consciência, desobediência civil ou provocação de legítima defesa), estando mais próxima do segundo nível proposto na classificação $\mathrm{DE}$ LA CUESTA AGUADO, o qual permite a exculpação de condutas que fossem reflexos da anterior infringência do princípio da dignidade da pessoa humana. Seriam, portanto, causas de exculpação supralegal por ausência de inexigibilidade de outra conduta - utilizando-se os mesmos fundamentos da existência de uma coculpabilidade estatal para despir o Estado do dever de exigir do agente conduta conforme a norma - sem, contudo, verificar o enquadramento das hipóteses dentre a situação de conflito de deveres, já que não se vislumbra, nesse caso, o conflito do agente na ponderação de bens, interesses ou deveres, mas o impulso ao descumprimento da norma ante um quadro de desestabilização familiar e financeira.

Dessa forma, afirma-se que a doutrina brasileira estaria dando à hipótese de conflito de deveres uma abrangência maior do que a mesma representa, para abarcar, em tal modelo, situações que não se amoldam à sua ideia central, qual seja, o conflito na ponderação de bens, deveres e interesses ao praticar a conduta.

Ora, ainda que se afirme que o crime mencionado fora cometido para salvaguardar direitos básicos do cidadão, a situação de adversidade anterior mais se amolda à motivação delitiva do que, propriamente, a um conflito do agente. Em outras palavras, uma eventual dúvida do agente entre cumprir a norma (e submeter-se às adversidades) ou descumpri-la, já jogaria por terra a alegação da não 
exigibilidade, demonstrando ser possível ao autor a resignação com sua situação (e busca de outras soluções), tanto que essa possibilidade foi por ele avaliada.

Acredita-se que, para a conduta apresentar uma carga valorativa tal que enseje seu enquadramento dentre os casos de não exigibilidade de conduta diversa, é certo que não deveria existir, na mente do autor, a possibilidade entre cumprir ou não cumprir a norma, mas, ao contrário, a sua escolha (desconforme à norma) lhe pareceria a única solução viável, já que cumprir a lei representar-lhe-ia um heroico esforço. O impulso ao descumprimento da norma, no caso analisado, mesmo traduzido em consequência da grave situação de adversidade do agente, não poderia se relacionar ao conflito de deveres exemplificado pelo estado de necessidade exculpante, no qual a escolha submetida ao autor da conduta não é representada pela dúvida entre "cumprir ou descumprir" a norma, mas entre a prática de atos representados por dois deveres relevantes, relacionados a bens jurídicos diversos, sendo certo que cada um dos caminhos atingiria, de alguma forma, o bem jurídico relacionado ao outro (o que deveria ensejar a eleição do "mal menor" falado por WELZEL).

Não se está a negar, pois, que os atos praticados no contexto de situações de adversidade financeira possam vir a ensejar, em dado momento, o afastamento da culpabilidade pela não exigibilidade supralegal. Tal verificação, contudo, não pode ser tratada como exemplo inserido da categoria "conflito de deveres", e não traz semelhança com os outros exemplos indicados pelo próprio CIRINO DOS SANTOS para o tema (a eutanásia de doentes mentais no regime nazista; o conflito enfrentado pelo maquinista da ferrovia que desvia o trem de carga desgovernado; a escolha, pelo médico, de qual paciente receberá a última máscara cardiopulmonar do hospital). 
Trata-se, portanto, de situação de não exigibilidade supralegal que não se alinha ao conflito de deveres, tampouco aos outros três modelos da doutrina brasileira, o que vem a demonstrar, mais uma vez, a fragilidade dessa classificação.

Já que se abordou a hipótese de dificuldades financeiras, interessante deixar consignado que a famosa tese da inexigibilidade de conduta diversa para justificar a falsificação de passaporte para ingressar nos Estados Unidos, alegando busca pela melhoria das condições de vida, também não se enquadra em nenhum dos modelos legais. Sobre o assunto, o Tribunal Regional Federal da 2a Região, através dos julgados da Primeira Turma Especializada ${ }^{85}$, vem afastando a culpabilidade nesses casos sob o argumento de que "o uso de documento falso com o claro objetivo de sair do país de origem para tentar a vida no exterior em melhores condições que as ali encontradas não legitima decreto condenatório", entendimento que ensejou inúmeros recursos sob esse fundamento, nos demais Tribunais federais. Em nenhuma outra turma, no entanto, a tese abordada ganhou tal notoriedade em prol dos argumentos defensivos, e o STJ já se firmou contrariamente ao tema ${ }^{86}$.

${ }^{85}$ A referida Turma criminal vem reconhecendo, à unanimidade, a excludente de culpabilidade nesses casos. A título exemplificativo, apontam-se os mais recentes: (I)TRF 2, ACR 8257, Rel. Des. ALUISIO GONCALVES DE CASTRO MENDES; Primeira Turma Especializada, E-DJF2R - Data::21/01/2011 - Página::6/7 ; (II) TRF2, ACR 8304, Rel. Des. ALUISIO GONCALVES DE CASTRO MENDES, Primeira Turma Especializada, E-DJF2R - Data::21/01/2011 - Página::6; (III) TRF2, ACR 7161, Rel. Des. ABEL GOMES, Primeira Turma Especializada, E-DJF2R - Data::18/05/2010 - Página::77.

${ }^{86} \mathrm{O}$ STJ analisou a matéria através dos recursos especiais no. 335.072/RJ, no. 518.635/RJ e no. 628.688/RJ. Nos dois primeiros casos o acusado teria despendido alta quantia para pagamento do passaporte falso, o que lançava dúvidas acerca da alegada dificuldade financeira, tornando mais fácil o afastamento da tese de inexigibilidade 
De qualquer sorte, são válidos para esses precedentes os mesmos argumentos relacionados à Teoria da Coculpabilidade do Estado aludida por CIRINO DOS SANTOS, e, mesmo se admitindo que as normas legais se tornem inexigíveis a ensejar a ausência de culpabilidade na falsificação e/ou o uso de passaporte falso, quando se consideram as melhores condições de vida do estrangeiro, é de se ter em mente que o agente não se via, no momento antecedente do crime, em hipótese de conflito de deveres, fato de consciência, desobediência civil ou excesso de legitima defesa. Aliás, as circunstâncias relacionadas à fraude no uso do passaporte - que implicam em razoável condição financeira para empreender viagens, manutenção no país estrangeiro e a motivação de ter um trabalho melhor remunerado (ganhando em moeda mais valorizada) - afastaria até mesmo a classificação de DE LA CUESTA AGUADO ao caso concreto, porque não se há de admitir que o fato de "ser submetido" a residir no Brasil e, aqui, tentar a vida, por mais adversa que seja considerada a situação econômica do país, represente ofensa à dignidade da pessoa humana.

Da análise conjunta desses julgados, pode-se perceber que, na atualidade, os casos submetidos à apreciação judicial fogem dos escassos exemplos de que dispunha a doutrina alemã quando da elaboração das teses e discussões acerca do estado de necessidade exculpante. Aliás, como acima demonstrado, muitos dos acórdãos brasileiros que se tem às mãos chegam mesmo a refutar a recente classificação trazida por CIRINO DOS SANTOS, ao não se enquadrar em nenhuma das hipóteses estudadas de não exigibilidade, seja legal ou supralegal.

de conduta diversa, e no último, foi reconhecida a prescrição da pretensão punitiva sem análise do mérito recursal. 
Ao tratar das causas supralegais de não exigibilidade, a doutrina de FÁBIO AZUMA aponta, além das quatro situações tratadas por CIRINO DOS SANTOS, a que ele denomina de "inexigibilidade pura e simples", para a qual AZUMA reservou os casos que não se adaptam àquelas quatro situações ${ }^{87}$. Para justificar o elenco de uma causa supralegal denominada "inexigibilidade pura e simples", AZUMA atenta que

Uma tese tão ampla e significativa quanto a inexigibilidade não está restrita somente a estas situações classificadas doutrinariamente. Repita-se à exaustão, toda vez que o sujeito, em razão das circunstâncias anormais agir sem dirigibilidade normativa, mesmo que esta ação não esteja prevista em tese legal e nem esteja ainda doutrinariamente classificada, haverá situação de inexigibilidade ${ }^{88}$.

A breve conclusão de AZUMA não apenas indica que os modelos apresentados já se mostram falhos, por não encobrir todas as causas já previstas, como chega a criar um novo modelo, no qual tenta enquadrar, de forma abrangente, todas as outras hipóteses de causas supralegais de não exigibilidade que não se encaixam na classificação aludida. Na realidade, embora a indicação de um novo modelo (a dita "inexigibilidade pura e simples") venha a ressaltar a insuficiência das fórmulas já antes apresentadas, registre-se que tal classificação nada mais é do que uma redução geral na qual se pretende incluir todas as hipóteses não classificadas nas causas supralegais outrora identificadas. Tal modelo, na realidade, não pode subsistir como classificação, ante a

${ }^{87}$ AZUMA, Felipe Cazuo. Inexigibilidade de conduta conforme a norma. Curitiba: Juruá, 2007, p. 121.

${ }^{88}$ Idem, ibidem, p. 121. 
completa ausência de elementos ou requisitos que identifiquem as dirimentes nele enquadradas. Até porque, como é óbvio, todas as outras causas supralegais poderiam se enquadrar na "pura e simples" inexigibilidade, para a qual não se firmou nenhum pressuposto, a não ser o fato de, dadas as circunstâncias, não se poder exigir do autor conduta distinta no caso hipotético.

Como já se disse, o reconhecimento das fórmulas (ou modelos) trabalhadas pela doutrina nacional e estrangeira nasceu das experiências submetidas aos Tribunais, sendo os modelos somados uns aos outros ao longo dos anos, a partir de experiências inseridas no contexto histórico e social das decisões judiciais que as reconheciam.

Sempre que surgia um novo caso criminal no qual, dadas as circunstâncias do fato, não se poderia exigir do agente conduta diversa da efetivamente praticada, e essa situação não se enquadrava nas hipóteses já previstas na lei, a doutrina se empenhava em classificála dentre os modelos pré-estabelecidos (a partir de decisões anteriores) ou, se assim não conseguisse, criava novo modelo de conduta. A verdade de WELZEL com a criação de três requisitos para o reconhecimento dessas causas supralegais não subsistiu às novas decisões, percebidas com a ampliação dos casos criminais. Tal fato ocorreu porque WELZEL enxergava a situação da inexigibilidade com o direito a ele posto (e no contexto de pós Segunda Guerra) a partir dos processos por ele estudados no âmbito dos Tribunais alemães. Não se poderia imaginar, por exemplo, que a modernidade traria o avanço da transfusão sanguínea e por motivos religiosos alguém se recusasse a dar a permissão de transfusão a seu filho, gerando a necessidade de tutela do direito penal à vida da criança. Não se previa, também, que a sociedade civil pudesse organizar-se de tal forma que, a partir de demonstrações públicas de bloqueios e ocupações de interesse e defesa do bem comum, incidisse em condutas formalmente típicas. Novos 
fatos sociais, outrora não experimentados, trouxeram ao direito a análise de novas situações, clamando por novas soluções. A experimentação das novas situações fáticas concretas foi criando, pouco a pouco, as decisões dos Tribunais penais no âmbito específico do tema estudado e, em seguida, as discussões doutrinárias de regulamentação do assunto.

A partir desses exemplos e da constatação da ineficiência dos modelos previstos, demonstrada está a inexistência de verdades inquestionáveis nesse campo, exsurgindo-se que as quatro delimitações de causas supralegais de inexigibilidade de conduta diversa apresentadas no Brasil não podem, jamais, serem tidas como os únicos caminhos a serem seguidos. É perfeitamente possível a identificação de situações não amoldadas a nenhuma dessas delimitações.

Ora, cada situação concreta é analisada pelo Juiz de forma única e subjetiva, dadas as circunstâncias nas quais a conduta se vê inserida, e tal dinamicidade justifica, inclusive, a aceitação da exculpante mesmo fora dos casos previstos em lei. Nesse raciocínio, reafirma-se a dificuldade de se pretender a formulação de regras objetivas para a aplicação dessa dirimente da culpabilidade.

Assim, a elaboração de caminhos, modelos, fórmulas ou delimitações de casos supralegais de inexigibilidade de conduta diversa torna-se falível, seja porque nunca vai abranger todas as situações concretas apresentadas - dado o subjetivismo inerente à própria análise do poder atuar de outro modo em cada situação concreta -, seja porque é sempre baseada em hipóteses já julgadas, voltada à análise do passado, e passível de ser superada por novas situações, no futuro.

No entanto, das causas supralegais já trabalhadas e comentadas na jurisprudência, vê-se claramente que mais um modelo 
deve ser admitido e considerado nos julgamentos penais, a seguir delineado.

8. A inexigibilidade supralegal como reação à violação de direito fundamental.

Como já afirmado, as classificações doutrinárias das hipóteses de inexigibilidade supralegal já não exaurem todas as situações submetidas à análise dos Tribunais. Cada situação concreta, pois, deve ser analisada pelo Juiz de forma única e subjetiva, esteja ou não enquadrada em um modelo doutrinário já estabelecido.

Tal conclusão, no entanto, não obsta a constatação de que, dos casos acima analisados, já se vislumbra uma nova causa supralegal ainda não tratada e evidenciada pela doutrina brasileira.

Diversos exemplos acima comentados, que redundaram no reconhecimento da inexigibilidade de conduta diversa supralegal, apresentam requisitos comuns e justificadores da aplicação da exculpante: a ofensa ou ameaça de ofensa a direito fundamental do cidadão, anterior ao ato desconforme à norma, que lhe tenha atingido ou venha a atingir-lhe a dignidade de tal forma que o direito não possa exigir-lhe a passividade. Em outras palavras, o direito não pode exigir, em algumas situações, que o cidadão fique inerte diante da ofensa ou ameaça de ofensa a direito fundamental seu ou de outrem.

Observa-se, $a b$ initio, a delimitação de três requisitos: (I) a violação ou tentativa de violação a direito fundamental, anterior ao ato desconforme à norma; (II) a dificuldade ou incapacidade do agente de se manter passivo diante da grave violação; (III) o ato desconforme a norma ser considerado resposta à violação do direito fundamental. 
Voltemos ao caso da jovem siciliana abusada pelo seu tio durante anos, com o conhecimento da tia. Após casar-se com um italiano, teve o casamento desfeito em razão da revelação ao seu esposo, pela própria tia, dos abusos e de suas relações sexuais com tio. Como reação aos abusos sofridos e à destruição de seu casamento pela tia, matou os tios. A motivação do crime não foi outra, senão a vingança. Não havia conflito de deveres ou outro modelo de causa supralegal doutrinariamente estudado. Também não se tratava de hipótese legalmente prevista que exculpasse sua conduta, e não se apresentam os requisitos da legítima defesa ou de alguma excludente de antijuridicidade. Mas o Tribunal popular a absolveu, entendendo pela impossibilidade de reprovar seu ato, já que, em sua pouca instrução, não poderia resistir ao ímpeto próprio de sua comunidade natal diante de ofensas tão graves à sua dignidade. As características próprias do caso demonstraram que, para a siciliana sexualmente abusada e posteriormente rechaçada pelo esposo, a violação à sua honra teria inegável peso na ofensa à sua dignidade como pessoa (o que caracterizaria o primeiro requisito); a pouca instrução, tida por "rudimentar", e a concepção oriunda da cidade natal italiana em revidar às ofensas à honra tornaram-na incapaz de manter-se inerte às agressões antes sofridas (segundo requisito), impulsionando-a a agir como consequência da primeira violação (terceiro requisito).

Esse tipo de causa supralegal utiliza as mesmas bases do segundo nível do juízo de exigibilidade firmado por DE LA CUESTA AGUADO: o ius puninendi não pode exigir condutas que representem o desprezo dos direitos e faculdades da pessoa humana, e esse critério permitiria a exculpação de condutas que fossem reflexos da anterior infringência do Princípio da Dignidade da Pessoa Humana.

Entendemos incluídos na garantia da dignidade da pessoa humana todos os direitos fundamentais previstos na Constituição 
Federal brasileira. Assim, ao decidir o caso do cidadão que agride o oficial de justiça por não permitir que o mesmo promova a intimação de sua esposa enferma, em dia de sábado à noite, o Supremo Tribunal Federal estaria evitando o defloramento do lar como asilo inviolável ${ }^{89}$. A tentativa de cumprir intimação em horário e dia inoportunos, sem a autorização do dono da casa, configuraria a violação ao direito constitucional da inviolabilidade do domicílio (primeiro requisito), não se podendo aceitar que o agente aceitasse tal violação impassível, principalmente considerando a enfermidade de sua esposa, que poderia se agravar (segundo requisito), e o repúdio à atitude do oficial de justiça, caracterizada como o crime de resistência, era consequência da anterior tentativa de violação ao lar (terceiro requisito).

É claro que a resposta deve ser adequada ou proporcional à anterior agressão. Caso o dono da casa, para evitar a intimação de sua esposa em horário inoportuno, recebesse o oficial de justiça com tiros de revólver, jamais se poderia alegar inexigibilidade de conduta

${ }^{89}$ Trata-se do Recurso Extraordinário no. 460.880-4/RS, já comentado no capítulo anterior. O recurso tratou da prática do crime de resistência contra a tentativa de um oficial de justiça que, no exercício de seu mister, pretendia intimar a esposa enferma do acusado em um sábado à noite, adentrando na residência do mesmo. O referido oficial dispunha de mandado judicial que autorizava, expressamente, o cumprimento da referida ordem até mesmo em dia de domingo, e em horário diverso daquele estabelecido na legislação. Julgando o feito, o STF entendeu que o caso deveria ser apreciado tendo como plano secundário a defesa do próprio domicílio. Assim, teve como caracterizada a ofensa ao preceito da Constituição Federal que tutela a inviolabilidade noturna do domicílio, pouco importando, nesse caso, a existência de ordem judicial que assim o autorizasse. Tendo por violado o inciso XI do art. 5o da $\mathrm{CF} / 88$, o qual reza que a casa é o asilo inviolável do indivíduo, ninguém podendo nela penetrar senão com o consentimento do morador - salvo em flagrante delito, desastre ou para prestar socorro, ou, ainda, durante o dia, com mandado judicial -, entenderam os Ministros do STF que não se podia exigir do agente outra conduta que não a de resistência à tentativa de intimação de sua esposa. 
diversa, sendo óbvio que nessa hipótese o direito poderia exigir que outro meio fosse utilizado pelo cidadão para evitar o acesso do funcionário público ao seu lar. Já a conduta de resistência ao cumprimento do ato ${ }^{90}$, adotada como reação, era passível de ser considerada resposta à anterior tentativa de violação ao direito fundamental.

Acredita-se também mais próximo desse modelo as hipóteses de condições sociais adversas, as quais entendemos inadequadas ao modelo de "conflito de deveres".

Recorde-se que, como já defendido, as situações relacionadas a crimes patrimoniais em situações de miserabilidade não fundamentariam hipóteses supralegais de conflito de deveres, já que essas últimas representam ponderações entre deveres ou interesses. Como já explicado, o agir impulsionado pelas dificuldades financeiras ou situação social adversa não importa em escolha de interesses ou de deveres: a situação adversa funciona como motivação da conduta contrária à norma. Diferentes são os casos nos quais qualquer conduta adotada infringirá um dever, e o agente procura escolher a conduta menos danosa (a exemplo do médico que escolhe quem usará a máscara cardiopulmonar, do empresário que deixa de recolher as contribuições previdenciárias nos casos de dificuldades financeiras da empresa para conseguir arcar com o salário dos funcionários). Como já aludido, a dúvida simples entre agir ou não em desconformidade com a norma não pode ensejar, por si, a inexigibilidade de conduta diversa, já que a ideia de inexigibilidade está relacionada justamente à falta de opção do

\footnotetext{
${ }^{90}$ Código Penal brasileiro: “Art. 329 - Opor-se à execução de ato legal, mediante violência ou ameaça a funcionário competente para executá-lo ou a quem lhe esteja prestando auxílio: Pena - detenção, de dois meses a dois anos”.
} 
agente, falta de opção que acaba por impulsionar à prática do ato contrário à lei.

Pois bem. Imagine que o agente se encontra em sérias condições de adversidade, caído no infortúnio, desempregado e preocupado com a alimentação dos filhos, que choram de fome e já não comem há alguns dias. Nessas condições, após mais um dia procurando emprego, sem sucesso, e sabendo que seus filhos esperam que ele leve para casa algum alimento, o agente furta uma bicicleta e a repassa adiante, recebendo, pela empreitada, duzentos reais. De posse do dinheiro, compra comida e retorna ao seu lar para alimentar seus filhos e esposa. O direito poderia exigir-lhe ação diferente?

Como já comentado, a jurisprudência entende que o desemprego e outros infortúnios não podem ser usados como justificativas para a delinquência. Ressalva, no entanto, o furto famélico e a situação extremada de penúria. Mas se defendermos a tese da Coculpabilidade do Estado nas situações de miserabilidade, o desemprego e a ausência de assistência estatal que importem em tormentosas consequências (como fome, falta de residência digna, falta de tratamento hospitalar) podem ser considerados violação à dignidade da pessoa, a ensejar a reação pessoal contra tal situação. Quando as condições sociais demonstram anterior ofensa às garantias fundamentais, a reação do cidadão à situação adversa pode ser vista como resposta à ausência de cumprimento pelo Estado dos deveres essenciais de assistência aos necessitados ${ }^{11}$ ? Em caso positivo, a

${ }^{91}$ Ressalte-se a já comentada doutrina de CIRINO DOS SANTOS, ao afirmar que "quando condições de existência social adversas deixam de ser a exceção transitória para ser a regra constante da vida das massas miserabilizadas, então o crime pode constituir resposta normal de sujeitos em situação social anormal' CIRINO DOS SANTOS, Juarez. Direito Penal: Parte Geral. 2a ed. Curitiba: ICPC Editora Lúmen Iuris, 2007, p. 341-342. DOTTI esclarece tratar-se da tese da coculpabilidade do 
conduta desconforme à norma tratar-se-ia de mais um exemplo de conduta eivada de inexigibilidade supralegal por caracterizar-se em reação à ofensa de direito fundamental.

Tem-se, então, mais esse modelo de causa supralegal de inexigibilidade de conduta diversa, frisando a ausência de taxatividade no rol elencado nesta obra, constatada pela existência de situações que não encontram enquadramento em nenhum dos cinco modelos e, ainda assim, representam situações de exculpação.

\section{CONCLUSÕES}

Quando se parte à catalogação doutrinária das hipóteses supralegais de não exigibilidade, vê-se que a discussão acerca da supralegalidade do tema, tão fomentada no século passado, desenvolveu-se para a tentativa doutrinária de dar segurança ao julgado supralegal, classificando em "modelos" de conduta as hipóteses já julgadas pelos Tribunais.

Isso porque, inexistindo uma fórmula na qual se elencassem circunstâncias comuns a todas essas causas de exculpação, natural que fosse desenvolvida a catalogação das situações já reconhecidas pela jurisprudência, tendo por objetivo, acredita-se, a orientação dos Magistrados na solução dos conflitos e a minimização das críticas da admissão das exculpantes supralegais (em sua maioria voltadas à incerteza jurídica e à impunidade que a adoção da causa supralegal poderia representar).

Estado, que, ao deixar de cumprir os deveres essenciais de assistência aos necessitados, acabou por renunciar ao dever de punição. DOTTI, René Ariel. Curso de Direito Penal: Parte geral. São Paulo: RT, 2010, p. 515. 
A partir da base firmada pela doutrina estrangeira, a alemã, nesse tocante, representada por CLAUS ROXIN, e a espanhola, por MUÑOZ CONDE, a doutrina brasileira também promoveu a delimitação dos 04 (quatro) modelos estudados de causa supralegal de excludente da culpabilidade.

Com a análise dos julgados brasileiros e comparação com essas classificações, chegou-se a interessantes conclusões. A primeira delas é que os critérios adotados já são insuficientes a exaurir, na atualidade, todos os casos de inexigibilidade supralegal já estudados. Considerando que os modelos de causas supralegais só surgem para a doutrina após a previsão do caso concreto submetido ao Judiciário (e não o contrário), era cediço que, sendo o direito uma ciência dinâmica e estando o legislador impossibilitado de acompanhar, na mesma velocidade, tal dinamismo, os 04 (quatro) modelos de causas supralegais de inexigibilidade de conduta diversa estudados pela doutrina (conflito de deveres / fato de consciência / provocação da situação de legítima defesa / desobediência civil) não se mostrassem absolutamente eficientes a abarcar todas as hipóteses.

Essa primeira conclusão, ao indicar casos práticos estranhos aos quatro modelos, demonstra uma necessidade de conjugação dos casos brasileiros com o raciocínio empreendido por DE LA CUESTA AGUADO, muito embora tal classificação também não tenha se mostrado perfeita e exauriente do tema.

A falibilidade das quatro fórmulas analisadas deu ensejo, aliás, a um quinto modelo, chamado pela doutrina de AZUMA de "inexigibilidade pura e simples", sem que esse autor tenha trazido, no entanto, quaisquer requisitos a essa nova classificação. Esse novo modelo nada mais seria, portanto, do que uma redução geral na qual se pretendem incluir todas as hipóteses não classificadas nas causas supralegais já identificadas, motivo pelo qual o mesmo não fugiu às 
críticas desse trabalho, não podendo ser considerado um tipo de causa supralegal de não exigibilidade de conduta diversa.

Dessa forma, longe de também pretender reduzir em fórmulas doutrinárias todas as hipóteses de causas supralegais já abordadas pelos Tribunais brasileiros, puderam ser identificados alguns requisitos comuns a tipos de causas supralegais não verificados nos quatro modelos já apresentados.

Trata-se da inexigibilidade supralegal como reação à violação de direito fundamental. A situação de inexigibilidade é verificada, nessas hipóteses, sempre que há ofensa ou ameaça de ofensa a direito fundamental do cidadão, anterior ao ato desconforme à norma (anterior, mas não iminente), a atingir-lhe a dignidade de tal forma que o direito não possa exigir-lhe a passividade ou inércia diante daquela ofensa. Em algumas situações, o direito não pode exigir que o cidadão mostre-se insensível à ofensa ou ameaça de ofensa a direito fundamental seu ou de outrem.

Essa nova causa de inexigibilidade de conduta diversa apresenta três requisitos: (I) a violação ou tentativa de violação a direito fundamental, anterior ao ato desconforme à norma; (II) a dificuldade ou incapacidade do agente de se manter passivo diante da grave violação; (III) o ato desconforme a norma ser considerado resposta à violação do direito fundamental, sendo a ele proporcional.

Como exemplo, apresenta-se o antigo caso da jovem siciliana abusada pelo seu tio durante anos, com o conhecimento da tia e que, depois, é absolvida pelo tribunal popular após ter promovido a morte dos tios. A motivação do crime jamais poderia ser classificada como legítima defesa, dada a ausência de iminência das agressões: tratou-se de resposta posterior às ofensas antigas que atingiram a dignidade da jovem de tal forma a impulsioná-la a resguardar sua honra. 
Como se demonstrou, esse tipo de causa supralegal utiliza as mesmas bases do segundo nível do juízo de exigibilidade firmado por DE LA CUESTA AGUADO (o ius puninendi não pode exigir condutas que representem o desprezo dos direitos e faculdades da pessoa humana), mas acrescenta que não apenas as ofensas ao Princípio da Dignidade da Pessoa Humana permitiriam a exculpação: todos os direitos fundamentais constitucionalmente assegurados merecem a tutela do direito penal no sentido de não permitir a punição daquele que, reagindo à violação de direito consti tucional seu ou de outrem, acabe por cometer um fato típico e antijurídico.

Outro exemplo da inexigibilidade de conduta diversa supralegal como reação à violação de direito fundamental é o verificado no caso do RESP 460.880-4/RS, com relação ao cidadão que agride o oficial de justiça por não permitir que o mesmo cumpra mandado de intimação à sua esposa enferma, em dia de sábado à noite. Nesse julgado, o Supremo Tribunal Federal absolve o acusado do crime de resistência por entender que a sua ação teve o intuito de resguardar o lar como asilo invioláve ${ }^{92}$. A tentativa de cumprir intimação em horário e dia inoportunos, sem a autorização do dono da casa, configuraria a violação ao direito constitucional da inviolabilidade do domicílio (primeiro requisito), não se podendo aceitar que o agente aceitasse tal violação impassível, principalmente considerando a enfermidade de sua esposa, que poderia se agravar (segundo requisito). O repúdio à atitude do oficial de justiça, caracterizada como o crime de resistência, era consequência ou reação da anterior tentativa de violação ao lar (terceiro requisito).

Para a consagração dos três requisitos, faz-se necessário observar que a reação do agente deve ser proporcional à agressão. Não

${ }^{92}$ Vide comentários ao Recurso Extraordinário no. 460.880-4/RS no capítulo 07. 
se admitiria, por exemplo, que alguém cometesse o crime de homicídio em razão de uma violação de correspondência, ainda que se reconhecesse ter havido ofensa à privacidade constitucionalmente assegurada com o acesso indevido a documentos privados. A separação dos casos em que houve ou não proporcionalidade da reação é verificada a partir da própria essência da conceituação da inexigibilidade de conduta diversa: se o autor, vítima de violação de seu direito constitucional, pratica ato desconforme à norma excedendo os limites da proporcionalidade e razoabilidade, o direito poderia, sim, exigir-lhe que agisse diferente e, nesse caso, não se chegaria nem a falar das circunstâncias concomitantes autorizadoras da inexigibilidade de conduta diversa. Não se teria, nesse caso, a falta de opção do agente que o impulsionasse ao ato desconforme à norma, ou seja, a situação já nem seria de inexigibilidade supralegal, e descabida a classificação dessa inexigibilidade em algum modelo, como a reação à violação de direito fundamental.

É inegável o reconhecimento de situações que não encontram enquadramento em nenhum dos modelos de causa supralegal estudados e, ainda assim, representam situações de exculpação. Assim, ante a forma como vem sendo apresentada as decisões judiciais sobre o tema no Brasil, representativas da aplicação das orientações modernas sobre o poder criador do Magistrado no direito penal, não se há de admitir a criação de classificações que tentem exaurir as hipóteses supralegais (sob pena de limitar-se a ampla liberdade de análise valorativa de cada situação, por cada Magistrado, sugestionando-o às hipóteses supralegais doutrinariamente estabelecidas). A proposta trazida nesse artigo, de indicação de mais um tipo de causa supralegal com base em elementos comuns alguns julgados, é, portanto, apenas exemplificativa. 
Por fim, deve-se dizer que discutir a existência de tipos de causas supralegais (chegando-se aos modelos descritos no item 02) é reconhecer, de antemão, que o legislador não pode prever tudo, dada a existência de um horizonte mais amplo do que as causas positivadas; assim, se esses próprios modelos doutrinariamente estabelecidos são firmados através das decisões já analisadas pelos Tribunais (voltados ao passado), a tentativa de objetivar essas causas em uma classificação de hipóteses supralegais já falharia em seu nascedouro, dada, na mesma medida que a legislação, a impossibilidade de a doutrina prever todos os casos ainda não submetidos ao direito. Ademais, a adoção da ideia de exigibilidade como norteadora da reprovação, que, por sua vez, quando inexistente, afasta o conceito de crime, já refutaria qualquer limitação a sua aplicação (seja legal ou doutrinária) que não a concretude do caso submetido à apreciação.

De qualquer sorte, sem tentar exaurir o tema diante da dinamicidade do direito, ficam aqui consignados os modelos de causas supralegais já reconhecidas pelo direito, esperando que novas situações sejam reconhecidas e, também, trabalhadas doutrinariamente.

\section{Referências}

AGUADO CORREA, Teresa. Manifestaciones del Principio de Inexigibilidad de Otra Conducta en las Categorias del Delito. In Revista Peruana de Ciencias Penales. Numero 17, 2005, pag. 53-84. Lima: IDEMSA, 2005 
ANTOLISEI, Francesco. Manuale di Diritto Penale: Parte generale. Milano: Dott A. Giuffre Editore, 1957.

AZUMA, Felipe Cazuo. Inexigibilidade de conduta conforme a norma. Curitiba: Juruá, 2007. 125 p.

BETTIOL, Giuseppe. Direito Penal: Parte Geral. Vol. II. Tradução brasileira e anotações de Paulo José da Costa Jr. e Alberto Silva Franco. São Paulo: RT, 1971, 331 p.

BITENCOURT, Cezar Roberto. Manual de Direito Penal. Parte geral. Vol. 1. 6ª ed. São Paulo: Saraiva, 2000. 707 p.

BRANDÃO, Cláudio. Teoria Jurídica do Crime. Rio de Janeiro: Forense, 2003. $243 \mathrm{p}$.

BRANDÃO, Cláudio. Culpabilidade: sua análise na dogmática e no direito penal brasileiro. In: Revista Portuguesa de Ciência Criminal, Coimbra, no. 02, p. 209-227, abril-junho 2005, Ano 15.

CIRINO DOS SANTOS, Juarez. Direito Penal: parte geral. Curitiba: ICPC Lumen Júris, 2007, 708 p.

DE LA CUESTA AGUADO, Paz M. Culpabilidad: exigibilidad y razones para la exculpación. Madrid: UCA, 2003. 244 p.

DOTTI, René Ariel. Curso de Direito Penal: Parte geral. São Paulo: RT, 2010. 830 p. 
FREUDENTHAL, Berthold. Culpabilidad y Reproche en el Derecho Penal. Tradução e prólogo de José Luis Guzmán Dalbora. Buenos Aires: Editorial B de F, 2003. 100 p.

GOLDSCHMITH, James. La Concepción Normativa de la Culpabilidad. Tradução de Margarethe de Goldschmidt e Ricardo C. Núnez. 2a edição. Buenos Aires: Editorial B de F, 2002. 143 p.

MUÑOZ CONDE, Francisco. La Objeción de Conciencia en Derecho Penal. In: NDP 96/A, pg. 87-102. Disponível em: < http://www.pensamientopenal.com.ar/ndp/ndp005.htm>; Acesso em: 20.11.2009.

MUÑOZ CONDE, Francisco; GARCIA ARÁN, Mercedes. Derecho Penal: Parte general. Valencia: Tirant lo Blanch, 2010, 636 p.

ROXIN, Claus. Derecho Penal: Parte General, Tomo I. Tradução da 2a edição por Diego-Manuel Luzón Peña, Miguel Diaz y Garcia Conlledo e Javier de Vicente Remesal. Madrid: Editorial Civitas, 2007 (reimpressão da edição de 1997), 1042 p.

TOLEDO, Francisco de Assis. Princípios Básicos do Direito Penal. São Paulo: Saraiva, 2008, 343 p.

WANDERLEY ANDRADE. A inexigibilidade de outra conduta como causa excludente de culpabilidade. Revista JUS, Revista Jurídica do Ministério Público do Estado de Minas Gerais. Belo Horizonte: Vol. 17, ano 1994. p. 381-407. 
WESSELS, Johannes. Direito penal: Parte geral (aspectos fundamentais). Tradução do original alemão e notas por Juarez Tavares. Porto Alegre: Sergio Antonio Fabris Editor, 1976. 204 p.

WELZEL, Hans. Derecho Penal Aleman. Tradução de Juan Bustos Ramírez y Sergio Yáñez Perez. 11ª edição. Santiago de Chile: Editorial Jurídica de Chile, 1997. 210 p.

WELZEL, Hans. O novo sistema jurídico penal: uma introdução à doutrina da ação finalista. Tradução de Luiz Regis Prado. 2a Edição. São Paulo: RT, 2010, 158 p. 